\title{
Arzu Pazarlaması: \\ BMW Markasının Çukur Dizisindeki Fantezi Sahnelerine Yönelik Bir Lacan Okuması
}

$\ddot{O} \mathbf{z}$

Mehmet Ali GENİ̧̧*

$\mathrm{Bu}$ çalışma, Jacques Lacan’ın arzu teorisinden hareketle, simgesel marka göstereninin sinema/dizi fantezi gerçekliğinde "fallus gösteren” olarak sahnelenmesinin, tüketici arzu/benliğiyle imgesel özdeşleşme (identification) süreci üzerinden, arzu nesne (object petit a) nedeni olarak nasıl kurulduğunu çözümlemeyi amaçlamaktadır. Bu amaca yönelik olarak çalışmada, Türkiye dizi piyasasında yoğun izlenme oranlarına sahip Çukur dizisindeki BMW fantezi sahnesinin ve bu sahnede yer alan Efe karakterinin Lacan ve Zizek okumalarına bağlı çözümlemesi yapılmaktadır. Bu çözümleme vasıtasıyla BMW markasının Çukur dizisindeki gerçeklik bağlamı üzerinden marka çağrışımları oluşturmaya ve dizi senaryosuna eklemlenen Efe karakteri üzerinden tüketici arzu/arzu nesnesini kurmaya çalıştığı gözlemlenmektedir. Zira özellikle Efe karakterinin yer aldığı fantezi sahnesinde BMW markasının, arzu nesnesi olarak (object petit a) konumlandırılmaya çalışıldığ belirlenmektedir. Böylece çalışmada BMW markasının Çukur dizisindeki fantezi sahnelerini, arzu pazarlamasında kullandığı ve bu sahnelerdeki gerçeklikle/karakterlerle özdeşleşen benlikler yoluyla marka değerini artırmayı amaçladığ savunulmaktadır. Çalışmanın temel katkısı, pazarlama/marka yazınında yoğun tartışmalara neden olan marka gösteren değerini, Lacan'ın arzu teorisiyle bütünleşik bir çerçevede açıklama ve çözümleme çabası olarak gösterilebilir.

Anahtar Kavramlar: Arzu Pazarlaması, Pazarlamada Psikanalitik Araştırmalar (PPA), Marka Gösteren Değeri, Jacques Lacan, Çukur.

\section{Desire Marketing: \\ A Lacan Reading Regarding Fantasy Scenes of BMW Brand in Çukur Series \\ Abstract}

Based on Jacques Lacan's theory of desire, this study aims to analyse how the staging of the symbolic brand signifier as "phallus signifier" in the fantasy reality of cinema/TV series is established as the object cause of desire (object petit a) through the process of imaginary identification with consumer desire/self. For this purpose, the analysis of the BMW fantasy scene in the Çukur series, which has high ratings in the Turkish TV series market, and the Efe character in this scene, based on Lacan and Zizek readings are made. Through this analysis, it is observed that the BMW brand tries to create brand associations through the context of reality in the Çukur series and to establish the consumer desire/desire object through the Efe character added to the series scenario. Because it is determined that the BMW brand is tried to be positioned as an object of desire (object petit a), especially in the fantasy scene where the character of Efe takes place. Thus, it is argued in the study that the BMW brand uses the fantasy scenes in the Çukur series in desire marketing and aims to increase its brand value through the selves identified with the reality/characters in these scenes. The main contribution of the study can be shown as the effort to explain and analyse the brand signifier value, which has caused intense debates in the marketing/branding literature, in an integrated framework with Lacan's theory of desire.

Keywords: Desire Marketing, Psychoanalytic Research in Marketing, Brand Signifier Value, Jacques Lacan, Çukur.

Geliş/Received: 15.07 .2021

Kabul/Accepted: 30.12 .2021

- Bu çalışma, insanlardan veri ve örnek toplamayı gerektiren, anket, inceleme, alan çalışması ve deney içeren araştırmalar kapsamında yer almaması nedeniyle etik kurul onay belgesi gerektirmemektedir.

\footnotetext{
* Dr. Öğr. Üyesi. Giresun Üniversitesi, Bulancak Kadir Karabaş Uygulamalı Bilimler Yüksekokulu, Uluslararası Ticaret ve Finansman Bölümü. m.aligenis@ giresun.edu.tr. ORCID: https://orcid.org/0000-0002-1503-6765. (Makale Türü: Araştırma Makalesi)
} 


\section{Giriş}

Sermaye birikimini önceleyen ekonomik sistemin şemsiyesi altında yaşanan 1929 bunalımından itibaren, tüketici davranışlarının yönetimi, temel bir pazarlama sorunu haline gelmiştir (Fullerton, 1988; Cochoy, 1998; Skålén, P., Fellesson, M. ve Fougère, 2006). Çünkü üretim kaynaklarına el koyma (sömürgecilik) üzerinden yürütülen artı değeri sahiplenme, kapitalizmin öncel biçimleri için yeterli olurken, sanayi kapitalizminin ürettiği krizleri aşmada yetersiz kalmış ve sermaye çıkarı adına toplumsal davranışı yönetme politikalarının uygulanmasını gerekli kılmıştır. Sermaye iktidarının (hegemonik rıza üretimine dayalı) toplumsal davranışı yönetme politikası, meta fetişizmine bağlanan çarpık değer/ilişkilerin (kültür/anlam üretimi) bireyin zihin/bedenine hâkim olması (öznellik üretimi) üzerinden kapitalist çelişkilerin gizlenmesini/onaylanmasını amaçlayan biyo-politik bir ideolojidir (Foucault, 1991; Negri ve Hardt, 2000; Zwick and Bradshaw, 2016). Bu açıdan sermayenin direkt olarak insan yaşamını, kültürünü ve öznelliğini sömürerek yeniden ürettiği kapitalist kültür ve öznelliklerin, insanı kendine yabancılaştıran öznellikler olarak, öznenin, sermaye iktidarına uyumlu davranış geliştirmesini amaçlayan ideolojik stratejiler olduğunu görmek gerekir (Zizek, 2006: 1550). Modern pazarlama teori ve uygulamalarının özellikle 1950’li yıllardaki tüketici davranışını anlama ve yönetmeye ilişkin paradigma dönüşümü, pazarlamanın, bu ideolojik stratejileri yerine getirme amaçlı işlev kazandığını gösterir. Çünkü modern pazarlama teori ve uygulamalarının 1950'li yıllardan itibaren gelişimi, tüketici davranış nedenlerini anlamaya yönelik bilgi içeriğini genişletme ve bu birikimi tüketici davranışını yönetme amaçlı kullanması üzerinden gelişmiştir (Tadajewski, 2006a: 173). Bu çerçevede pazarlama uzmanlarının disiplinler arası bir araştırma alanı olarak tüketici araştırmaları (consumer research) ölçeğinde çalışma alanlarını genişlettikleri görülür (Holbrook, 1987).

Pazarlama yazınında özellikle 1950'li yıllardan itibaren yoğun ilgiyle karşılanan tüketici araştırmaları, pozitivist tüketici araştırmaları ve yorumsal tüketici araştırmaları olarak iki temel alan çerçevesinde sınıflanır (Holbrook, 1987; Calder ve Tybout, 1987). Bu ayrım aynı zamanda pazarlamada anaakım ve eleştirel/radikal yaklaşımların ayrım noktasına da işaret eder (Stern, 1990; Tadajewski, 2006b). Çünkü pozitivist tüketici araştırmaları, tüketicinin bilinçli bir karar verici olarak rasyonel bir seçim (homo-economicus) yapabileceği varsayımına dayanır. Nitekim 1960'lı yıllardan itibaren gelişen istatistiksel yöntemler vasıtasıyla uygulanan kantitatif çalışmalar ile pozitivist çabalar, tüketicinin makul bir rasyonel karar verici olarak modellenebileceği varsayımı üzerinden hareket eder ve ana akım pazarlama yönelimi bu yönde şekillenir (Anderson, 1983; O'shaughnessy, 1987). Böylesi bir soyutlama, tüketicinin, her tür bastırma, uyum ve manipülasyon süreçlerinden azade, bir problem çözücü veya rasyonel karar verici olarak ele alınması yanılsaması üretir (De Ruyter ve Scholl, 1998). Fakat yorumsal araştırmalar, tüketiciyi, tercih nedenlerinin tam olarak bilincinde olmayan varlıklar olarak okur ve odak grup görüşmeleri aracılığıyla gerçek tercih nedenlerinin anlaşılabileceğini savunur (Dichter, 1960). Çünkü bu çözümleme, insanın doğal bir varlık olmaktan öte kültürel bir varlık olduğuna ilişkin 
(yapısalcı) psikanalitik vurgunun, pazarlama araştırmalarındaki yansımasıdır ve belli bir toplumsallaşma ve kültürün parçası olan insanın, tüketim yapma ve satın alma davranışının sosyopsikolojik etkilerden soyutlanmasının mümkün olmadığını gösterir (Alderson, 1952; Buttle, 1989; Bargh, 2002). Zira psikanalitik araştırmalar göstermiştir ki insan davranışının bilinçli kısımlardan oluştuğunu varsaymak, yalnızca buzdağının görünen kısmıyla uğraşmak anlamına gelir (Freud, 2012).

Tüketici davranışının rasyonellikten uzak ve istatistiki model kalıplarını aşan niteliği, pazarlama uzmanlarının psikanalitik (özellikle Sigmund Freud) araştırmalardan beslenen çalışmalar yapmalarına neden olmuştur (Cluey ve Desmond, 2005). Bu çalışmalar incelendiğinde, arzunun, tüketim davranışını etkileyen oldukça önemli bir motivasyon kaynağı olduğu savunulur (Belk, Ger ve Askegaard, 2003). Keza arzunun, bilinçdışı bir güç olarak, tüketicilerin davranışını yönetmede önemli bir araç olarak görülmesi, özellikle pazarlama iletişim çalışmalarında yoğun şekilde çalışılmasına neden olmuştur (Elliot, 1997; Bagozzi, 1995; Reichert ve Lambiase, 2013). Bu açıdan arzu pazarlaması, psikanalitik öğretilerin pazarlama uzmanları tarafından tüketici davranışını anlama ve motive etme amaçlı kullanılma girişimidir. Diğer bir deyişle arzu pazarlaması, tüketim davranışının dürtü ${ }^{1}$ nedenlerini anlama ve simgesel/imgesel boyutta yeniden üreterek (sömürerek-üretme), bilinçdışı etki düzeyinde, tüketicinin kendi arzusu olarak konumlandırılması stratejisidir (Dichter, 1960; Oswald, 2010). Pazarlama uzmanlarının ideolojik dil ve söylem yapıları üzerinden geliştirdikleri iletişim stratejileri (reklam, halkla ilişkiler, marka, vs.) sömürerek-üretilen (insanı kendine yabancılaştıran) arzunun sahnelendiği temel gösterenlerdir (Papatya ve Geniş, 2018). Bu gösterenler içinde marka, tüm diğer geleneksel işlevlerinin ötesinde, gösteren değerine bağlı şekilde tüketiciyi kimliklendirebilmesi (identification) açısından oldukça önemli bir işleve sahiptir (Aaker, 1997; Holt, 2006). ${ }^{2}$ Keza Gorz’un (2011: 60) “markalar, parasallaştırabilir sembolik değerlerdir" açıklamasına bağlı olarak markalar, gösterge zinciri üzerinden ürettikleri anlam/arzuyu, tüketici (özne) benliğiyle özdeşleştirme çerçevesinde, sadık müşterilerini kimliklendirebilmektedirler. Arvidsson (2005) markaların, kapitalist sermaye birikimi adına üstlendiği bu rolü, para-sermaye-para (M-C-M) dönüşüm sürecinde, artı değeri artırma işlevi üzerinden okur. Arvidsson, markaların, özel fiyat (premium price) ve marka değerlendiricilerine (brand awareness, brand identity, brand loyalty, vs.) bağlı olarak sermaye birikimini artırdığını savunur. Marka değerlendiricileri, markanın, tüketicilerin "gerçek" dünyalarındaki yerinin (imajının) ölçülmesiyle elde edilen veriler olarak, pazarlama maliyetlerini düşüren ve markanın finansal yatırım değerini artıran sosyo-psikolojik verilerdir (Aaker, 2009). Özel fiyat ise Arvidsson'un (2005: 250) "bir çift Nike ayakkabısı için fazladan para ödemeye hazır olabilirim, eğer o ayakkabılar, üyesi

\footnotetext{
${ }^{1}$ Dürtü, Freud okumasında içgüdü, Lacan okumasında sapma (drive/drift) olarak tanımlanır. (Lacan, 2006: 680; Zupancic, 2008: 15). Van Leeuwen (2017: 360) belirttiği gibi, Lacan açısından dürtü (drive/drift), eksikliğin varlığg ve bu eksikliği örtme girişimindeki anlam üretiminin uyuşmaz görünümünde aranmalıdır. Yani eksikliğin varlığı, belli bir anlam ve duyu üretimini teşvik ederken; anlam, eksikliğin üstünün örtülmesi girişimidir. Bu açıdan dürtü, "varllğın ve anlamın kendi heterojenliğindeki imkânsız ortak eklemlenmesini" ifade eder (Zupancic: 2008, 28). Arzunun şekil aldığı ve bilinçdışının öznesinin kurulduğu alan, bu kurucu dürtünün/sapmanın (drift) alanıdır. Yani, bir eksik ve bu eksiği örtme girişimde ona karşılık gele(meye)n anlamın çelişik gerçekliğidir.

${ }^{2}$ Holt'a (2006: 300) göre "kapitalizmin temel işlevi olarak markalanma, sermaye birikiminin ayırt edici bir biçimidir".
} 
olduğum lise akran kültüründe yüksek statülü bir kişilik sergilememe izin veriyorsa" sözüyle ve Zizek' in (2014: 266) "bir markaya fazladan para ödememizi sağlayan şey hiç’tir" sözüyle açıkladığ1 gösterilensiz-gösteren değeridir; yani marka imajıdır.

Gösterilensiz-gösteren değeri olarak marka imajı, Lacan'ın, Ötekiyle yaşanan tamlık yanılsaması çerçevesinde doyum sağladığına imgesel düzeyde inanılan nesne olarak açıkladığı arzu nesnesine (object petit a) oldukça benzerdir. Fakat marka hiçbir zaman tam olarak arzu nesnesi olarak konumlanamaz; sadece belli bir süre için öznede kapanmaz boşluğu kapattığı yanılsaması/fantezisi üreterek "arzu nesne nedeni” oluşturabilir (Zizek, 2008a; İzmir, 2013). Bu çerçevede çalışma, Türkiye'de yoğun izlenme oranlarına sahip Çukur Dizi’sinde BMW marka göstereninin, Lacan'ın arzu nesne'sinin nedeni olarak nasıl konumlandırıldığını çözümleme amacındadır. Bu amacı gerçekleştirmek üzere, çalışmanın ilk bölümünde, yazın araştırması olarak pazarlamada psikanalitik çalışmaların temel aç1lımlarına yer verilmektedir. İkinci bölümde, Lacan'ın arzu teorisi, özne benliğinin eksik kuruluş diyalektiği olarak belirttiği üç düzen (gerçek, imgesel, simgesel) çerçevesinde açıklanmaktadır. Ayrıca yine aynı bölümde marka gösteren değerinin "arzu nesne" nedeni olarak tüketici imgeleminde nasıl konumlandırıldığı, düğüm noktası (point de caption) süreci üzerinden açıklanmaktadır. Son bölümde ise Zizek'in ve Todd McGowan'nın Lacan okumalarına bağlı geliştirdikleri psikanalitk film çözümlemesine bağlı şekilde, Çukur Dizisi özelinde Efe karakterinin yer aldığı fantezi sahnesinde, BMW markasının “arzu nesnesi” olarak konumlanma girişimi çözümlenmektedir.

\section{Pazarlamada Psikanalitik Araştırmalar}

Pazarlamada psikanalitik araştırmalar (PPA), 1930'lu yıllardan itibaren üzerine çalışılan bir alan olmasına rağmen, anaakım yazının kenarında radikal bir alan olarak konumlandırılır (Pratkanis ve Greenwald, 1988; Lazarsfeld, 1934). Bu konumlandırmanın temelde iki nedene bağlı olduğu söylenebilir. İlk neden Avrupa/Amerika merkezli egemen paradigmanın modern pazarlama teorisini pozitivist bilim yapma kuralları ölçeğinde evrenselleştirme girişimidir (Tadajewski, 2006a). İkinci neden ise psikanalitik yaklaşımlardan beslenen pazarlama uygulamalarının, etik dışı olduğu kanısı üzerinden, insanları yanlış ihtiyaçlara yönlendirme, kandırma ve manipüle etme girişimi olarak sunulması ve marjinalleştirilmesidir (Packard, 1957; Nelson, 2008; Stern, 1990; O’Shaughnessy, 2015). Fakat özellikle 20. Yüzyılın sonlarından itibaren, ağırlıklı olarak eleştirel pazarlama akademisyenleri tarafından, psikanalitik yaklaşımlara yönelik artan bir ilginin oluştuğu söylenebilir (Tadajewski, 2006b).

PPA, psikanalizin kurucusu Sigmund Freud'un psikodinamik yani, kişinin bilinçdışı dünyası ve bu gücün davranışlar üzerindeki etkisini keşfetmesinden (1893-1895) yaklaşık otuz y1l sonra (1923) yazında yer almaya başladığı söylenebilir (Geçtan, 1996: 18). Nitekim Edward L. Bernays'ın ve Ernest Dichter'ın çalışmaları bu alandaki öncü kaynaklar olarak kabul edilir. Halkla ilişkilerin kurucusu olarak kabul gören Bernays, (1923) ve (1927) çalışmalarında, kitle davranışının kontrol edilmesinde, görünmez 
yönetim (iletişim) ilkelerinin uygulanmasının, kitlelerin farkında olmadıkları bilinçdışı arzularını harekete geçirdiğini savunur. Viyana okulundan ve Paul J. Lazarsfeld'in yaklaşımlarından beslenen ve Amerika'da motivasyon araştırmalarının öncüsü olarak kabul edilen Dichter ise psikanalitik uygulamaların pazarlama alanında temellenmesinde ve gelişiminde önemli katkılar sağlamıştır (Tadajewski, 2013; Lazarsfeld, 1934; Dichter, 1986; Schwartzkopf ve Gries, 2010).

Dichter'ın, Procter \& Gamble, Chrysler ve Esso Exxon şirketlerinde uygulamış olduğu kampanyalar oldukça başarılı olmuş ve deneyimlerini akademik çalışmalar üzerinden paylaşmıştır (Fullerton, 2007). Örneğin, Dichter (1947) çalışmasına, iş adamı (businessman) ile psikoloğun insanları biçimlendirmek ve motive etmek gibi benzer görevlerinin bulunduğunu açıklamakla başlar. Zamanının pazar araştırmalarında kullanılan yöntemlerin yetersiz ve eski olduğunu, bu araştırmaların sadece yüzeye yani tüketicilerin ne söylediklerine ve düşündüklerine odaklanarak, rasyonel satın alma niyetini ve miktarını ölçtüğünü belirtir (Schwarzkopf, 2015). Dichter'a göre tüketici, çoğu zaman satın alma niyetine ilişkin gerçek motivasyon nedenlerinin farkında değildir. Bu açıdan pazar araştırmasının, neden (why) sorusuna cevap veren bir araştırma olmasını ve bilinçdışı arzuları da hesaba katmasını önerir. Reklam etkinliğinin artırılmasında psikolojik bakışın önemini açıkladığı (1949) çalışmasında Dichter, reklam mesajını alan tüketicinin zihninde (mind) neler olduğuna odaklanılması gerektiğini savunur. Zira reklam gerçekliğinin tüketici zihninde hangi hatıraları canlandırdığına, onu hangi düşe sürüklediğine, heyecanlandırıp heyecanlandırmadığına, iyi mi kötü mü hissettirdiğine odaklanarak temel satın alma nedeninin bulunabileceğini belirtir. Ayrıca bu çalışmasında, gerçek reklamın basit bir iş olmadığını belirterek psikolojik bakışın, reklamcılığa katkısını dondurma örneği üzerinden şu şekilde açılar; "birçok dondurma reklamı, tüketiciyi en iyi kalite ve lezzet üzerinden kendine çekmeye çalışır. Fakat psikolojik araştırmalar dondurmanın şehvet/seks düşkünlügüyle (voluptuous) ilgili çekici bir yönü olduğunu ortaya koymuştur. Bu açıdan eğer bir reklam gerçekliğinde, seks düşkünlüğü tüketici arzusu olarak konumlandırllırsa başarılı bir reklam uygulanmış olur" (Dichter, 1949: 63). Benzer şekilde Dichter, deodorantların sosyal bir gruba kabul edilme ve güvenle ilişkili olduğunu, Amerikalı erkeklerin arabalarını bir metres olarak kullandıklarını ve kadınların sabunu kötülüklerden arınmanın bir aracı olarak gördüklerini açıklamıştır.

Dichter'in pazarlamada motivasyon teorisine önemli katkı sağladığı çalışması, 1960 yılında yayınlanan Arzu Stratejisi (Strategy of Desire) çalışmasıdır. Bu çalışmasında, insanların gündelik hayatlarında birçok kararı alırken farkında olmadıkları motivasyon nedenlerinin psikanalitik yaklaşımlar aracılığıyla belirlenebileceğini belirtir. Dichter'a göre bu motivasyon nedenleri kültürel, irrasyonel ve bilinçdışı nitelikler taşır ve insanda bir gerilim (tension) oluşturarak davranışa dönüşür (Dichter, 1960: 36). Pazarlama araştırmalarının ampirik verilerle uğraşmak yerine odak grup görüşmeleri üzerinden sürdürülmesini ve böylece motivasyon nedeninin katarsis (catharsis) süreci üzerinden açıklanabileceğini savunur. İnsanların bir ürün satın almakla kimliklerinin bir yönünü satın aldıklarını ve herhangi bir markaya sadık kalmakla kendi kimliklerine sadık kaldıklarını belirtir (Dichter, 1960: 60). Ayrıca, 
markaların bir ayna işlevi görerek insanın kendini yeniden keşfetmesini sağlayan bir araç olduğunu ve bu durumun insan ruhunu keşfetmenin yeni devrimci yolu olduğunu açıklar (Dichter, 1960: 91). Özellikle araba modelleri üzerine yapmış olduğu incelemelerde, arabaların fallik (phallic) bir sembol olarak işlev kazandığını savunur (Dichter, 1960: 91). Bu çerçevede Dichter'ın yaygın tüketici ürünlerindeki gizli anlamların bir tipolojisini geliştirdiği söylenebilir (Krishnan ve Trappey, 1999: 453).

Pazarlama yazınında Dichter'ın çalışmalarının yanında tüketici satın alma nedenlerinin belirlenmesinde modern psikoloji/psikanalizin önemli katkı sağladığını açıklayan çalışmalar yer alır. Bu çalışmalar incelediğinde, tüketicinin satın alma süreç ve nedenlerinin akılc1/ekonomik olmaktan öte kültürel ve psikolojik olduğuna ilişkin giderek artan bir vurgunun yapıldığı görülür. Örneğin, Wroe Alderson (1952) çalışmasında, satın alma tercihine ilişkin tüketicinin, problem çözme aşamalarından hareket ederek, psikolojik yaklaşımların bu tercih nedenine yönelik kapsamlı bir açıklama getirebileceğini savunur. Çünkü Alderson'a göre problem çözme süreci (sanıldığı üzere) sadece tüketicinin sunulanlar arasından kendisine en uygun olanı rasyonel biçimde tercih etme süreci olarak açıklanamaz. Tüketici tercihinin belirlenmesinde tüketicinin özlemleri, toplumsal yapılar/değerler ve reklamların etkisi söz konusudur. $\mathrm{Bu}$ açıdan psikolojik öğrenme teorileri, Freud'un bilinçdışı açıklamaları ve toplumsal kimlik biçimleri üzerinden araştırma yapılmasını önerir. Sidney J. Levy (1959) çalışmasında, insanların satın alım tercihlerinin ekonomik olmaktan uzaklaştığını ve sembolik tüketimin giderek arttığını belirtir. Levy’e göre modern ürünler giderek psikolojik şeyler olarak kabul edilmekte ve tüketim, para harcamanın yanı sıra (psikolojik rahatlama olarak) enerji harcamanın bir yönü haline gelmektedir. Bu açıdan tüketim nesnesiyle tüketicinin kurduğu ilişki biçiminin iletişimsel yönü (dil, imgesel ve simgesel) üzerinden (toplumsal cinsiyet, kimlik, kültür, sınıf, vs.) satın alma davranışını motive eden nedenlerin belirlenebileceğini savunur. Philip Kotler ise tüketici davranışını farklı teorilere bağlı olarak (Marshall'ın ekonomik, Pavlov'un öğrenme, Freud'un psikanalitik, Veblen'in sosyo-psikolojik ve Hobbes'un organizasyon faktör) açıkladığı (1965) çalışmasında, motivasyon/psikanalitik yaklaşımların reklamcılık uygulamaları vasıtasıyla etkili olabileceğini belirtir. Kotler, tüketicinin özel dünyasına ait umutları, rüyaları ve korkuları üzerinden oluşturulacak motivasyonun, rasyonel nedenlere nazaran daha etkili olabileceğini savunur (Kotler, 1965: 42).

Pazarlama yazınında psikanalitik araştırmaların, psikanalitik teorinin kendi içindeki görüş ayrılıklarına bağlı şekilde farklılaştığı görülür (Parsons, Maclaran ve Chatzidakis, 2017). Bu açıdan Sigmund Freud'un rüyaların yorumu, kişilik, cinsellik, arzu, narsisizm (Forest, 2016; Desmond, 2012); Melanie Klein'in kişilik, nesne ilişkileri teorisi, narsisizm (Oswald, 2010; Desmond, 2012); Heinz Kohut'un benlik psikolojisi (Boyd ve Held, 2005); Carl Gustav Jung'un arketip, psikolojik tipoloji (Dominici, vd. 2016; Lamlein, 2014; Kurultay, 2017) ve Jacques Lacan'nn ayna evresi, benlik, eksiklik olarak arzu, narsizm ve söylem teorileri (Oswald, 2010: Stavrakakis, 2006; Elliot, 1997) üzerinden geliştirilen çalışmaların yazında yer aldığı görülür. Pazarlama yazınında yer alan bu çalışmalara bütünsel 
çerçevede bakıldığında, çoğu araştırmacı tarafından Freud'un alana ilişkin temel katkılarının yoğun şekilde takip edildiği söylenebilir (Desmond, 2012; Güler, 2019). Nitekim bu çalışmalarda tüketim davranışına neden olan dürtülerin bilinçdışı kaynaklı olduğu kabul edilir. Fakat bu çalışmaların birbirlerinden farklılaşmasının nedeni, tüketim davranışına neden olan bilinçdışı güçlerin hangi kaynakta (libido, cinsellik, içgüdü, dürtü, anı izi, benliğin yanlış üretimi, tarihi kalıntı, toplumsal bastırma, arzu ve dilsel) konumlanacağına ilişkin görüş ayrılıklarıdır. Lacan'ın “bilinçdışı dil gibi örgütlenir" ve "bilinçdışı ötekinin söylemidir" sözlerinden hareketle, Lacan bakış açısını takip eden pazarlama çalışmalarında tüketim davranışının nedeni olan dürtülerin, sadece bedensel haz, libido veya kişinin kendi içsel devinimlerinden kaynaklanmadığı, aynı zamanda öznelerarası dil kullanımının özneyi kendine yabancılaştırarak Öteki söyleminin nesnesi olarak kurmasıyla, hem özne benliğinin narsist yapısının hem de tüketim davranışa neden olan dürtülerin anlaşılabileceği savunulur (Oswald, 2010). Bu açıdan pazarlama yazınında (tüketici davranışının anlaşılması ve motivasyonuna yönelik) Lacan okumalarının temelde iki çerçeve üzerine yoğunlaştı̆ğ görülür. İlk çerçeve Lacan'ın ayna evresi (imgesel özdeşleme) modelidir (Williamson, 1978). İkinci çerçeve Öteki’nin söylemi içinde bir anlam arayışı olarak öznenin benliğini (ve arzusunu) kurma (simgesel özdeşleşme) sürecidir (Oswald, 2010). Her ne kadar çoğu pazarlama araştırmasında bu iki çerçeve temel bir ayrım noktası olarak düşünülse de Zizek'i takip ederek bu ayrımın Lacan'cı özne ve arzu konumlarının anlaşılmasını zorlaştırdığı söylenebilir. Zira Zizek’e göre “imgesel özdeşleşme, kendi kendimize hoş göründüğümüz imgeyle 'olmak istediğimiz şeyi’ temsil eden imgeyle özdeşleşmedir; simgesel özdeşleşme ise, tam da gözlendiğimiz yerle; kendi kendimize hoş, sevilmeye değer görünecek şekilde baktığımız yerle özdeşleşmedir" (Zizek, 2008a: 121) ve "imgesel biçimi belirleyen ve ona egemen olan şey simgesel özdeşleşmedir" (Zizek, 2008a: 125). Bu açıdan çalışmada, tüketici arzusunun bilinçdışı boyutu, Lacan'ın gerçek-imgeselsimgesel düzen olarak açıkladığı diyalektik sürecin parçalanması üzerinden değil bütünleşik diyalektiğine bağlı şekilde okunur.

\section{Lacan'ın Arzu Teorisi ve “Arzu Nesne” Nedeni Olarak Marka}

Lacan'a göre arzu, insan yaşamının temel devinim nedeni olmakla birlikte, Freud'un biyolojik cinsel arzularından farklı şekilde ruhsal (psyche) bir arzudur (Harding, 2007). Çünkü Lacan düşüncesinde arzu, insan öznesinin sosyal/biyolojik olgunlaşma evrelerinin toplumsal yasa/dil tarafından zapt edilmesiyle oluşan ve fakat zapt edilme öncesinin de bu oluşum sürecinde etkin olduğunu belirten süreç üzerinden açıklanır. Lacan'ın Gerçek-İmgesel-Simgesel Düzen olarak açıkladığı bu süreç, öznenin cinsel ve zihinsel özelliklerinin bizzat toplumsal anlamlar (Öteki) tarafından bastırılarak üretildiği diyalektik çerçeveyi belirtir (İzmir, 2013: 181-221). Bu diyalektik çerçeve içinde özne, biyolojik ihtiyacının giderilmesine ilişkin imgeyi, dil/toplum yasasına uygun simgeyle (Ötekinin gösterenleriyle) açıklamaya çalışan ve bu nedenle ortaya çıkan (hiç kapanmayacak olan) boşluğu, savunma/fantezi yoluyla kapatmaya çalışan, bölünmüş özne olarak yapılanır. Bu açıdan insan öznesinin arzusunu anlayabilmek ve açıklayabilmek için, özneyi bu üç düzenin diyalektiği içinde sürekli hareket 
eder konumda çözümlemek gerekir. Zira Lacan kuramında İmgesel, Gerçek'in yarattı̆̆ belirsizliğe karşılık histerik bir savunma, Simgesel de Gerçek'in yarattığı çelişkilerin karmaşasına karşı kurulan saplant1lı bir savunmadır (İzmir, 2013: 178).

Bu diyalektik çerçevede Lacan'c1 arzu, "eksiği olmayan bütün bir varlık" olma çabasıdır (Lacan 2006: 679; İzmir, 2013: 269). Eksik kalma kaygıs1, öznenin "Gerçek" döneminden gelen "bütün olma" yanılgısı/kalıntısından kaynaklanır. Çünkü gerçek döneminde özne (bebek), ihtiyaçlarını karşılayacak ilk öteki olan annesiyle (bakıcısıyla) bir bütün olarak, tek bilincin var olduğuna inandığı bir gerçeklikte yaşar. Anneyle bütün olma hem beden hem de bilinç düzeyinde bebeğin yaşadığı tamlık yanılsamasıdır ve öznenin yaşam süreci boyunca eksiklik kaygısına eşlik edip arzulayacağı bütünlüğün temellendiği zemindir. Arzu, yitirilmiş olan bu gerçekliğe yönelik zihinsel/dilsel bir temsildir (Fallus Olma arzusu) ${ }^{3}$ ve hiçbir temsil, yitirilmiş olanın yerine geçemeyecektir (Lacan, 2013; İzmir, 2013: 262). Nitekim Ödipal dönemde Babanın Adı metaforunun özne tarafından benimsenmesiyle bastırılan/dağılan anneçocuk bütünlüğünü (kastrasyon) yeniden yakalama arzusuyla dolu özne, öznelerarası dil kullanımının, otoritenin ve toplumsal yasanın (Babanın Adı) baskın kuralları çerçevesinde dürtü kontrolünü öğrenmek ve arzusunu dile getirmek (talep yoluyla maskelemek) zorunda kalır (İzmir, 2013: 296-298). Arzunun, talep (dil) aracılığıyla temsilinin imkânsız olması, eksik biçimde tanımlanmasına aracılık eder. Konuşarak dilin simgesel evrenine dâhil olan öznenin arzusu, toplum tarafından onaylanmış, kendisine saygın bir konum verilmesine yönelik duyulan arzudur; yani Öteki’nin arzusudur (Lacan, 2017: 249; İzmir, 2013: 299-309). Çünkü Lacan düşüncesinde arzu, bir nesneden çok bir özneye yöneliktir (Gammelgaard, 2011: 971) ve köken olarak Hegel'in tanımladığı “Ötekinin arzusunun arzusu” olarak yapılanır (İzmir, 2013: 269). Çocuğun ilk öteki olan annesiyle bütün olma arzusu, çocuğun kendini, ötekinin arzu nesnesi (fallik nesne) olarak kurma çabasını gösterir. Fakat ilk ötekinin arzusu, Öteki gösterenler zincirinin bir parçası olduğu için ve özellikle ikinci doyum deneyiminden sonra çocuk, Ötekinin arzusunun arzusu olarak (fallus gösteren) Öteki gösterenlerinin tutsağı haline gelir. $\mathrm{Bu}$ tutsaklık, Lacan'ın arzu grafiğinin üçüncüsünde, Hamlet oyununa bağlı olarak açıkladığı "Che vuoi" sorusu üzerinden, özne arzusunun nasıl kurulduğunu da açıklar. Çünkü dile bu girişle beraber özne, arzu nesnesini elde etmek için öteki'ye yöneltilen bir dizi talepten geçmek ve talebine ulaşmada öteki'nden gelen itirazlara boyun eğmek zorunda kalır (Lesourd, 2018: 106).

Lacan için arzu ebedidir ve tatmin edilmesi imkânsızdır. Organik bir ihtiyacın karşılanmasından ziyade, "talebin ihtiyaçtan koptuğu aralıkta şekillenmeye başlar" (Lacan 2006, 689). Arzunun, Gerçek doyum zevkine (jouissance) bağlı olarak, Öteki diyalektiği çerçevesinde (talep biçiminde) dile getiril(eme)mesi, arzunun, tatmin edilemez biçimde kurulmasının nedenidir (Lacan, 2015: 22-23). Yani özne imgeleminde arzu, çocukluk döneminden kalan anne (öteki) sevgisine yeniden kavuşabilme çabası

\footnotetext{
${ }^{3}$ Lacan Fallusu, ödipal üçgende arzunun göstereni olarak tanımlar ve arzunun, fallus olma ya da fallik nesneye sahip olma diyalektiği biçiminde kendini gösterdiğini belirtir (Lacan, 2013).
} 
olduğu sürece, arzunun talep olarak dile getirilmesi hep bir boşluk bırakacaktır. Çünkü çocuğun yaşadığı ilk doyum, sadece fiziksel ihtiyaçların karşılandığı bir doyum değil; aynı zamanda çocuğun anne şefkati, bakışları ve arzularıyla tam bir bütün olma biçiminde yaşadığı doyumdur (İzmir, 2013: 276). Bu doyuma ulaşma arzusundaki öznenin, Öteki diyalektiğinden geçerek simgesel biçimde talep ettiği herhangi bir nesne, arzuyu tatmin edecek nesne olmayacaktır. Çünkü talebin nesnesi, bir gereksinim nesnesi olmasına rağmen, arzunun doyuma ulaşmasını sağlayamaz. Arzunun doyuma ulaşabilmesi için özne imgeleminde, ötekiyle yaşanan deneyimle birlikte kodlanmış nesnenin var olması şarttır (İzmir, 2013: 241-262). Lacan'ın arzu nesnesi (object petit a) olarak açıkladığı bu nesne, Ötekiyle yaşanmış tamlık yanılsaması (bakış, şefkat, vs.) üzerinden kodlanmış imgesel bir nesnedir (Lacan, 2017: 281-288). Bu açıdan talep nesnesi, öznenin doyuma ulaşması için hep yetersiz kalacaktır. Diğer bir deyişle, talep nesnesi, ihtiyaç-şefkat bütünlügüne bağlı oluşan imgesel bir kayıt olarak arzu nesnesine nazaran, yeri doldurulamaz bir boşluk kalmasına neden olur (Zizek, 2008a: 245). Bu boşluk, öznenin zihninde, öteki'nin tanımlanamaz kayboluşuyla oluşan boşluktur.

Özne, ilerleyen yıllarda bu boşluğu kapatma arzusuyla, arzu nesnesini arar. Fakat arzu nesnesi yok nesnedir. Yalnızca vekilleri/temsilcileri aracılığıyla var olur ve bu temsilciler sadece fantezi yoluyla boşluğu kapattığı yanılsaması üretebilir. Nitekim Zizek'in “enjoy your cola” söylemiyle açıkladığı gibi, arzu nesnesinin temsilcisi durumundaki markalı ürünler, bu boşluğu ancak özneye bir fantezi kurdurarak ya da mistik fazlalıkları olduğuna inandırarak doldurma çabasındadır (Zizek, 2008c). İzmir'in (2013: 277) "marka, nesne a ile yakından ilişkilidir. İnsanlar markayı satın alır; malı değil” cümlesiyle açıkladığı gibi markalar, somut faydaları (gereksinim nesnesi) üzerinden değil; kültürel, fetişist ve Ötekinin söylemine bağlanan bilinçdışı çağrışımları üzerinden, tüketici (özne) zihninde (imgeleminde) arzu nesnesi olarak konumlanmayı amaçlarlar. ${ }^{4}$

Markalı ürünlerin arzu nesnesi olarak, özne arzusundaki kapanmaz boşluğu doldurabilme girişimi, Zizek'in deyişiyle, ancak Lacan'cı düğüm noktası (point de caption) kavramıyla açıklanabilir. Zizek’e (2008a: 112) göre düğüm noktası "sözcük olarak, gösterenin kendisi düzeyinde, verili bir alanı birleştiren, özdeşliğini/kimliğini kuran sözcüktür. Deyim yerindeyse, 'şeyler'in kendilerinin birbirleri içinde kendilerini tanıtmak için göndermede bulundukları sözcüktür". Zizek'i takip ederek, eğretileme (metafor) ve metonimi düzeyinde düşünüldügünde, marka sembollerinin, yüzer-gezer gösterenlere dikilmesi/düğümlenmesinin anamorfik ${ }^{5}$ niteliğini de anlayabiliriz. ${ }^{6}$ Çünkü marka imajının tüketici zihninde anlamlandırılmasında kullanılan gösterenin, somut bir nesneye göndermede bulunması (çoğunlukla) gerekmez; nesnenin özdeşliğinin çekirdeğini, gösteren kurar (Zizek, 2008a: 115). Yani

\footnotetext{
${ }^{4}$ Elbette bu, tüketici zihninin fethedilme savaşıdır (rekabetidir). Her marka söyleminin tüketicide böyle bir etki yaratması beklenemez. Tüketicinin marka söylemine düğümlenmesi (point de caption), marka söylemiyle özdeşleşmesi/kimliklenmesi gerekir (Ries ve Trout, 2001).

${ }^{5}$ Anamorfoz: görme duyusuyla dolaysız olarak algılanamayan, belirli bir biçime sahip değilmiş gibi görünen nesnelerin, özel bir bakış açısından algılanabilir olmasıdır. Yani simgesel düzenin (dil), bakış açımızı kaydırmasıdır (Zizek, 2008b: 28).

${ }^{6}$ Zizek, markaların anlam üretiminde yüzergezer göstergelere dikiş sürecini, "Marlboro Ülkesi Amerika" ve "Amerika Coca Cola'dır" söylemleri üzerinden okur (Zizek, 2008a: 112).
} 


\section{Mehmet Ali GENIȘ}

\section{Arzu Pazarlaması: BMW Markasının Çukur Dizisindeki Fantezi Sahnelerine Yönelik Bir}

Lacan Okumas1

markaların anlam üretimi için kullandığı gösteren, göstergelerarası yapı (Ötekinin söylemi) içinde anlam ifade eder, fakat gösterileni yoktur. Yine Zizek (2014: 266) "bir metaya markast yüzünden daha fazla para ödediğimizde, bu fazla parayı ürünün somut özellikleri için değil, hiç için, sirf gösterge için öderiz" der. İşte markanın somut faydasının ötesinde fanteziye, mite ve fetişizme bağlanan anlamlarını kazandıran bu hiçtir; yani arzu nesnesinin nedeni olarak kurgulanan gösterilensiz-gösteren (boş gösteren) değeridir.

Bir boş gösterenin anlamlı hale gelebilmesi, ancak onun, Öteki söyleminin (gösteren zinciri) içinde kendine yer bulmasıyla/sabitlenmesiyle mümkündür. Benzer bir anlam bulma çabası öznenin benliğinin/arzusunun kurulma süreci için de geçerlidir (Lacan, 2017: 216). Zizek’e göre "point de caption” aynı zamanda “öznenin gösterene dikildiği noktadır; yani bireyi, ona belli bir ana gösterenle seslenerek özne olmaya çağıran noktadır" (Zizek, 2008a: 118). Çünkü özne, her zaman onu, öteki için temsil eden bir gösterene/göreve sabitlenmelidir. Fakat gösteren zincirinin anlamını geri dönüşlü olarak sabitleyen her dikme işlemi belli bir boşluk bırakır. Bu boşluk arzu grafiğginin üçüncüsünde açıklanan "Che Vuoi” (benden bir şey talep ediyorsun ama aslında ne istiyorsun?) ile gösterilir. Zira özne, simgesel ağ içinde niye bu konumu işgal ettiğini bilmez. Zizek'e göre "Che vuoi”, arzu ve talep arasındaki kapanmaz boşluğun simgesi olarak histerik soruyu (ben niye senin olduğumu söylediğin şeyim?) doğurur. Histerik soru, öznenin simgesel ağa (görevi sahiplenişi) dâhil oluşudur (Zizek, 2008a: 130). Bu dâhil oluş, öznenin, simgeseldeki (Öteki'deki) eksiklikle yüzleşme ve onu kapatma girişimi olarak fantezi düzeyinde gerçekleşir. Çünkü Zizek’e göre fantezi “Che Vuoi” sorusuna verilen cevaptır; yani sorunun yarattığı boşluğu cevapla doldurma girişimidir. Burada fantezinin görevi, "sembolik düzenin kapayamadı̆̆, dilin kendisinin bile dillendiremediği, en nihayetinde "adlandirllamayan” olarak adlandırdı ̆̆ tarifsiz hiçliğe, yutan karadeliğe, Gerçek'e, kapılmadan tutunabilmelerini să̆layan bir yanılsama yaratmaktır" (Keskin, 2008). Bu yüzden Zizek, fantezinin alışılmış tanımının (arzunun gerçekleştirilmesini temsil eden hayali senaryo) biraz yanıltıcı ve muğlak olduğunu savunur. Ona göre "fantezi-sahnesinde arzu gerçekleştirilmez, tatmin edilmez, kurulur; ona nesneleri sunulur. Fantezi, sayesinde nasıl arzulayacağımızı ögreniriz” (Zizek, 2008a: 135). Bu açıdan fantezinin rolü, bir yerlerde tatmin edici bir arzu nesnesi olduğu yanılsaması üretmektir (McGowan, 2018: 315).

Zizek (2008a: 136) açısından arzu ekonomisinde fantezinin rolü, bilgi sürecinde aşkın şematizminin oynadığ role benzer. Çünkü Tomsiç’in de belirttiği gibi kapitalist dünyada "sermayenin kendi kendisini doğurur gibi görünmesi, nitelikle değerin doğrudan örtüştüğü fetişist fantezide temellenir" (Tomsiç, 2017: 147). Nesnenin fetişleştirilmesi, özne bölünmüşlüğünü giderdiği yanılsaması üreterek özne ile joussiance arasında tek değerli bir ilişki kurulabileceğini iddia eder (Tomsiç, 2017: 262). Çünkü bir metanın piyasadaki başarısı, üretim bağlamına işaret eden izlerin, fabrika tozunun, makine kalıplarının ve hepsinden önemlisi emek sömürüsünün izlerinin silinmesine bağlıdır. Arzulanabilmesi için metanın, baştan çıkarıcı bir pırıltıyla piyasaya sürülmesi gerekir 
(McGowan, 2018: 315). Bu açıdan fantezi, temel bir imkânsızlığın boş yerini dolduran bir senaryo, boşluğu maskeleyen bir perde olarak, kapitalist çelişkilerin farkında olunarak yok sayılmasını mümkün kılan bir yanılsama üretir (Zizek, 2008a: 143). Böylece Zizek'in “yamuk bakmak” olarak açıkladığı “hiç nesnesine belli bir arzu nesnesi değeri kazandıran çarpıtılmış bakış"ın nesne değerini yüceltme girişimi de açıklığa kavuşur (Zizek, 2008b: 27). Çünkü fantezi, toplumsal gerçekliği hayali bir eylemle çarpıtarak, imkânsız nesneye (arzu nesnesi) ve öznenin "gerçek hayatta" erişmeyeceği zevke (joussiance) anlık bir erişim imkânı sağlar (McGowan, 2012: 60). Bu çerçevede fantezinin politik ideolojisi, kapitalist gerçekliği yansıtırken aynı anda onu gizleyen, onu dayanılır kılan, içindeki çelişkilerden bir hiç (marka göstereni) çıkartıp, bu hiçi, tüketicinin "arzu nesnesi” olarak kurgulayan sahnelenme biçimlerinde kendini gösterir ve çözümlenebilir.

\section{Çukur'da Sahnelenen BMW Fantezisi}

Yazın incelendiğinde ideolojik bir sahne olarak sinemanın birçok farklı yöntemle çözümlendiği görülmektedir (Metz, 2012; Gabbard ve Gabbard, 1999; Mascelli, 1965; Papatya ve Özdemir, 2015). Bu yöntemler içinde psikanalitik film çözümlemesi, kurgusal sinema gerçekliği üzerinden, sinema yönetmeni ve karakterlerinin analizan düzeyinde konumlandırılarak, psikanalitik kuramın geliştirdiği yöntemler (rüya yorumu, narsisizm, imgesel/simgesel özdeşleşme, söylem, arzu, fantezi, vs.) vasıtasıyla çözümlenmesi süreci olarak tanımlanabilir (Metz, 1982; McGowan, 2012; McGowan, 2020; Zizek, 2006; Bakır, 2008; Ormanl1, 2011; Turan, 2013; Erkılıç, 2015). Bu yöntemlerden biri olan fantezi çözümlemesi, sinema (imgesel-simgesel) gerçekliğine gizlenen "gerçeği” çözümleme/anlamada yetkin bir çerçeve sunmaktadır. Nitekim sinemanın politik boyutunu ilk defa Charlie Chaplin ve Sergei Eisenstein'ın eserlerine bağlı okuyan McGowan için fantazmatik senaryo, arzuyu ulaşılabilir kılan bir anlatımdır. McGowan'a göre fantazmatik senaryo, “arzunun kendisinin içine yerleştirebildiği bir sahne sunar. Dolayısılla arzunun temeldeki belirsizliğini hafifletir. Fantezi, arzunun tatminsiz öznesini, imgesel zevkle doyuma ulaşmış bir özneye dönüştürür” (McGowan, 2012: 77). ${ }^{7}$ Benzer bir görüşle Zizek'in (2008b: 20) belirttiği gibi “öznenin arzusunun koordinatlarını vermek, nesnesini saptamak, öznenin onun içinde benimsediği konumu belirlemek, tam da fanteziye düşen roldür. Özne ancak fantezi yoluyla arzulayan özne olarak kurulur”. Yani sinema/dizi gerçekliğinde sahnelenen fantezi, imkânsız nesne olan object petit a'nın bakış biçiminde (karşılaştırınız yamuk bakmak) düzenlenmesine olanak sağlayarak, arzunun çarpıttığı nesne olan object petit a'yı kurar ve arzu kanatlanır (McGowan, 2012: 61; Zizek, 2008b: 27). Bu açıdan fantezi sineması, egemen ideolojiye uyum ölçeğinde, tüketicinin (öznenin), tüm fiziki zorluklarına rıza göstermesini sağlayacak olan imgesel bir zevki (arzu nesnesine ulaşabilme fantezisi üzerinden) mümkün kılar. Çalışmanın bu bölümünde, fantezi politikasının (diğer işlevlerini bir kenara bırakarak) bu temel işlevi üzerinden, Çukur dizisindeki BMW fantezi sahnesi çözümlenmektedir.

\footnotetext{
${ }^{7} \mathrm{Bu}$ fantezi, kendini üreten ideolojiyi gizleme işlevini üstlenir (Zizek, 2008a: 77).
} 
Çukur dizisi, Türkiye dizi piyasasında yoğun izlenme oranlarına sahip, içinde psikanalitik öğeler taşıyan popüler dizilerden biridir (İpek, 2020: 133). ${ }^{8}$ Popüler olmasının nedeni Türkiye gerçekliğine (göç, tekinsiz gecekondu yaşamı, fakirlik, aile yaşamı, vs.) oldukça yakın olup, bir o kadar da uzak durmasından (kabadayılık, egemen yasaya karşı durma, biz para biriktirmeyiz adam biriktiririz söylemi, fantezi boyutu) kaynaklanıyor olabilir. Çünkü dizininin yönetmeni olan Gökhan Horzum'un diziyle aynı adı taşıyan kitabının önsöz bölümünde, Çukur'un İdris'i olan Ercan Kesal, dizi hakkında şunu söylemektedir; "gerçekliği yeniden icat ederek başka bir dünyanın mümkün olabileceğini göstermek ve muhatabımızı da buna inandırmaktan başka bir şey yapmıyoruz” (Horzum, 2019: 10).

Çukur, İdris Koçovalı'nın (Baba) İstanbul'a göç edip, bataklığı kurutarak inşa ettiği, diğer göç edenlere/çaresizlere kol kanat gerdiği ve yasal olmayan bazı yollardan para kazanılan bir mahalledir (Sarı ve Nezir, 2020). Bu mahalle, İdris'in dostu Emmi tarafindan dizinin ilk bölümünün başlangıcında şu şekilde tanımlanır; “herkesin bir yuvası var şu hayatta, bizimki de Çukur'dur. Gözümüzü Çukur'da açarız, son nefesimizi Çukur'da veririz. Dışarda başımız belaya girse kendimizi Çukur'a atarız. Nerde olursak olalım hep Çukur'a geri döneriz. Birbirimizi tanımasak bile birbirimizi biliriz” (Horzum, 2019: 17). Temelde dizi, Baba İdris'in kurallarıyla/yasasıyla sorun yaşayan, ama yine de o'nu kaybetmekten korkan, beş oğuldan biri olarak babasını öldürme lanetiyle (2. Sezon 67. Bölümde öldürür) yaşamak zorunda kalan, Yamaç karakteri üzerinden sahnelenir. Dizinin ikinci bölümünün başlangıcında Yamaç'ın sesinden şu sözlerini dinleriz; “Hayat pis şakalar yapmayı çok sever, beş gündür tanıdı̆̆ın bir adamla evleniverirsin, ertesi sabah kalktığında yanında bulamazsın, bir not bile birakmadan sırra kadem basmıştır. Babanla hayatının en büyük kavgasını edersin o kavga seni olmak istediğin adam yapar. O kavga seni ailenden uzaklaştırır... Ne ölüme ne ölüme diyerek çıkarsın büyüdü̈̆ün evden. Bundan daha mutlu olamam dediğin anda, abinin öldüğ̈̈nü babanın yoğun bakımda olduğunu duyarsın. Hayatının aşkını, sırf ona bir zarar gelmesin diye bilmediği bir şehirde yapayalnı bırakıp gidersin... Dönmem dediğin eve dönersin" (Horzum, 2019: 45). Bu çerçevede Çukur dizi gerçekliğinin ve özellikle başkarakterlerinin farklı psikanalitik çözümleme araştırmalarına konu olacak içeriğe sahip olduğu söylenebilir. ${ }^{9}$ Fakat çalışmanın temel amacı ölçeğinde, bu bölümde, Efe karakterine ${ }^{10}$ odaklanılarak, Yamaç'ın da içinde yer aldığı fantezi sahnesinde, BMW markasının arzu nesnesi olarak konumlanma girişimi çözümlenmektedir.

Çukur dizisinde Efe karakteri 2. bölümün 58. dakikasında ilk kez görünür. Bu sahne Çukur'un Abisi

\footnotetext{
${ }^{8}$ Dizinin (çoğunlukla) anlamı geri dönüşlü kurma çabası, oidipus kompleksi, babanın adı, tekinsiz, karakterlerin sürekli geçmiş anı izi üzerinden benliklerinin parçalı kuruluşunun sahnelenmesi vs. dizinin içeriğinde bulunan psikanalitik öğelerden bazılarıdır. Özellikle dizi gerçekliğinde Çukur'un birçok kez farklı gruplar tarafından ele geçirilmeye değer görünüp sahipliğinin sürekli el değiştirir şekilde sahnelenmesi, bir nesne olarak Çukur'un, "object petit a" biçiminde kurgulanmış olabileceğini düşündürür.

${ }^{9}$ Zira dizi yönetmeni Gökhan Horzum'a göre: Çukur dizisi arızalı karakterleri içinde barındırır. "Asıl mesele, seyreden insanların kendilerini, bu arızalı karakterlerinin birinde/ikisinde bulabilmesidir” (Marka konferansı, 2018)

${ }^{10}$ Efe karakteri, dizi izleyicisi konumundaki gençlerin özdeşleşebileceği (kendilerini bulabilecekleri) bir karakter olarak, Türkiye sosyo-ekonomik gerçekliğine uyumlu şekilde tasarlanmış görünmektedir (Üstündağ, 2019; Güven, 2019).
} 
(daha sonra Babası olacak) Yamaç'ın, sorduğu sorularla Efe'yi tanımaya/tanımlamaya ${ }^{11}$ çalıştı̆̆ı, Efe'nin "Che Voui”" sorusu üzerinden arzu nesnesini ( $a r a b a)$, simgesel biçimde belirttiği soru cevap diyaloğu şeklinde hazırlanmış görünmektedir. ${ }^{12} \mathrm{Bu}$ sahnede geçen diyalog şu şekildedir:

Efe: Abi hoş geldin, abi başın sağ olsun hani yapabileceğimiz bi şey bi emrin varsa abi burdayız biz.

Yamaç: Adın ne senin

Efe: (ürkek bir sesle) ...Efe abi

Yamaç: Kaça gidiyorsun Efe?

Efenin arkadaşı: bu son senemiz abi bizim

Yamaç: Güzel...

Yamaç: (Yamaç elini Efe'nin omzuna atar ve Efe'ye dönüp sorar) Efe kızlarla aran nasıl?

Efe: Sessiz kalır... ${ }^{13}$

Efenin arkadaşı: Yamaç abi, o birine âşık ama konuşamıyor.

Yamaç: (olmaz öyle şey der gibi biraz şaşırmış) Niye konuşamıyorsun oğlum madem seviyorsun?

Efe: (biraz hırçın) Ya abi konuşmayacaksın ya... Geçeceksin arabayla önünden, bak o zaman ne oluyor? Ama bizde araba nerde? (arzu nesnesi olarak araba göstereninin dile getirilmesi)

Yamaç: E ayarlarız araba...

Efe: (heyecanli) Cidden mi abi?

Yamaç: Ayarlarız da sen kullanamazsın ehliyetin yok daha (Baba'nın adl/yasasının kastrasyon etkisi)

Efe: Abi sıkıntı olmaz ara sokaklardayız

Yamaç: Yok ben kullanacağım sen camdan sarkarsın

Efe: Valla mı abi? Sen bana bunu yap, kapında köle olurum abi, ölürüm senin için abi! (efendinin söylemi konumlandirur)

Yamaç: Dur lan dur ölmek falan yok... Hadi görüşürüz çocuklar.

Efe karakterini daha iyi tanımamıza olanak sağlayan 3. bölüm 50. saniyedeki diyalog özne arzusunun, öteki dolayımından geçerek nasıl kurulduğunu ve arzu nesnesinin bu kuruluş süreci üzerinden nasıl inşa edildiğini gösterir niteliktedir. Zira bu diyalogda, Efe'nin Çukur'da yaşayan boyacı bir baba'nın oğlu olduğu, boyacılık yapmak (para kazanmak) için okula pek uğramadığı anlaşılır. Ayrıca bu sahnede, araba göstereninin arzu nesnesi konumu, ötekiyle yaşanacak ilişki düzeyinde şu şekilde kurulmaya devam eder;

...diyalog bu kesimden itibaren alınmıștır.

Efe: (bir şeyler bekler gibi) Ya abi?

Yamaç: Ayarlayacağız oğlum tamam kaçmıyoruz bir yere. Haa kız mı kaçıyor?

Efe: Yok abi yok, o da burda.

Yamaç: E tamam, sen burdasın, ben burdayım.... (eksik olan nedir? Efe'nin sevdiği genç kadın mı araba mı?)

Efe: Ya abi büyüksün... Var mı bi emrin abi?

Yamaç: Var, okula git.

Dördüncü bölümde Efe, Yamaç’ın bu emrine uymuş şekilde okul kıyafetleriyle çıkar karşımıza.

\footnotetext{
${ }^{11}$ Efe karakterinin öteki söylemi üzerinden göstergeler zincirine düğ̈̈mlenmesi (point de caption).

${ }^{12}$ Krş. Efendi köle diyalektiği (Papatya ve Geniş, 2019: 1039).

${ }^{13} \mathrm{Krş.} \mathrm{"Che} \mathrm{voui”} \mathrm{sorusu} \mathrm{ve} \mathrm{Zizek'in} \mathrm{açıkladığı} \mathrm{Meryem'in} \mathrm{şaşırma} \mathrm{hali} \mathrm{(Zizek,} \mathrm{2008a:} \mathrm{130).}$
} 
Fakat sahnede üç arkadaşıyla birlikte okulda değil, İdris'in oğlu olduğu daha sonra anlaşılacak olan Vartolu Sadettin'in (Salih) Çukur'a gizlice soktuğu uyuşturucuyu satan elemanından (Tavşancı) uyuşturucu alma çabası içindedir. Bu sahnede Efe, yine parası olmayan ve bu nedenle uyuşturucuyu arkadaşı aracılığıyla borç üzerinden talep eden bir karakter olarak tanımlanır. Aynı sahnede, Efe'nin uyuşturucu kullanan bir ergen olarak gösterilmesi, Lacan'ın keyif (pleasure) ve zevk (enjoyment/joussiance) farklılaşmasına bağlı olarak Zizek'in yaptığı ayrımı akla getirir. Keyif almak isteyen özne, hesaplı olarak hedonik hazlarına ulaşmaya çalışır. Fakat zevk almak isteyen özne (jouisseur) "ölümcül zevk fazlalı̆̆ içinde varlı̆̆ını tamamlamaya hazırdır" (Zizek, 2016: 483). Bu açıdan Efe karakterinin, kapitalist dünyanın zevki hemen ulaşılabilir kılma söylemi üzerinden kendini yok etme pahasına potansiyel bir uyuşturucu kullanıcısı olarak sahnelendiği söylenebilir.

5. bölümde Efe, Tavşancı ile birlikte yıkık bir evde, kullanmış oldukları uyuşturucu nedeniyle baygınlık geçiren arkadaşının başında çıkar karşımıza. Sonraki sahnede Enver, (Efe'nin arkadaşı) uyuşturucu nedeniyle ölür. Bunun duyulmasını istemeyen Tavşancı, Efe'yi bıçaklar ve Efe'nin Enver'i hastaneye götürmek için getirdiği arabanın bagajına koyarak ıssız bir yerde bırakır. Daha sonra uyuşuk halde bulunan Tevfik'in (Efe'nin diğer arkadaşı) konuşturulmasıyla Yamaç durumdan haberdar olur; Tavşancıyı sorgular ve Efe'yi bırakılan yerde yaralı şekilde bulur. Yamaç Efe'yi kanı çekilmiş şekilde hastaneye birakır.

5. bölümdeki bu sahneden sonra Efe karakteri, üzerinde çözümleme yaptığımız fantezi sahnesinin de içinde yer aldığı 27. bölüme kadar gösterilmez. Dizide Efe karakterinin kayboluş ve yeniden ortaya çıkma süreci, izleyicide bir unutma ve yeniden hatırlama (anı izinin bilinçdışı etkisi) süreci olarak tasarlanmış (arzunun bilinçdışında kuruluşu) olabilir. Çünkü Efe ve Yamaç arasında geçen 27. bölümdeki diyalog sahnesinde, 2. bölümdeki diyalog yeniden hatırlatılır. Ayrıca 27. bölümde Efe ve Yamaç arasında geçen diyaloğun başlangıcında, Yamaç’ın Efe'ye hayatının pamuk ipliğine bağlı olduğunu hatırlatmasından sonra Efe'nin bir daha uyuşturucu kullanmamaya yemin ettiği ${ }^{14}$ görülür. Bu yeminden sonra Yamaç Efe'ye sorar;

Yamaç: Senin bir mesela vardı o noldu?

Efe: Haaa duruyo abi.

Yamaç: Sen de duruyorsun galiba

Efe: Aynen abi hatta daha fena ateşler alevler falan filan... (arzunun dile getirilemez yapısı)

Yamaç: Nerde kızın evi? (diye sorduktan sonra 2. bölümdeki şu sahne tekrar hatırlatılır)

\footnotetext{
${ }^{14} \mathrm{Bu}$ yemin, Efe'nin, hesaplı keyif alan hedonist bir yapıda benliğini kurma girişimi olarak okunabilir (Zizek, 2016).
} 
Yamaç: Efe kızlarla aran nasıl?

Efe: sessiz kalır...

Efenin arkadaşı: Yamaç abi o birine âşı ama konuşamıor.

Yamaç: (olmaz öyle şey der gibi biraz şaşırmış) niye konuşamıyorsun oğlum madem seviyorsun?

Efe: (biraz hırçın) ya abi konuşmayacaksın ya geçeceksin arabayla önünden bak o zaman ne oluyor? Ama bizde araba nerde? (arzu nesnesi olarak araba göstereninin dile getirilmesi)

Efe: (şaşkın ve heyecanlı) Cidden mi abi? Abi burdan hemen solda

(Bu sırada Yamaç arabayı düz sürer ve Efe ısrar eder)

Efe: Abi solda!

Yamaç: Lan tamam bi dur!

Daha sonra Yamaç’ın arabayı neden düz sürdüğü anlaşılır. Çünkü az önce kullandıkları (farklı bir marka) arabayı değiştirmek üzere gitmişlerdir. Bu sahnedeki araba değişimi, Efe'nin (yani izleyicinin) herhangi bir arabayla ötekinin bakışını (sevgisini) kazanamayacağını anlaması açısından önemlidir. Çünkü ötekinin bakışını kazanmak için, ötekinin arzusunun arzusu olan "fallus gösteren" gereklidir. Bu açıdan Yamaç, Efe'ye verdiği sözü tutmak üzere üstü açık, havalı bir arabanın (BMW) $)^{15}$ içinde, Efe'yle birlikte, Efe'nin sevdiği genç kadının bulunduğu mekânın çevresinde dolaşacaklardır (Fantezi Sahnesi, 2021).

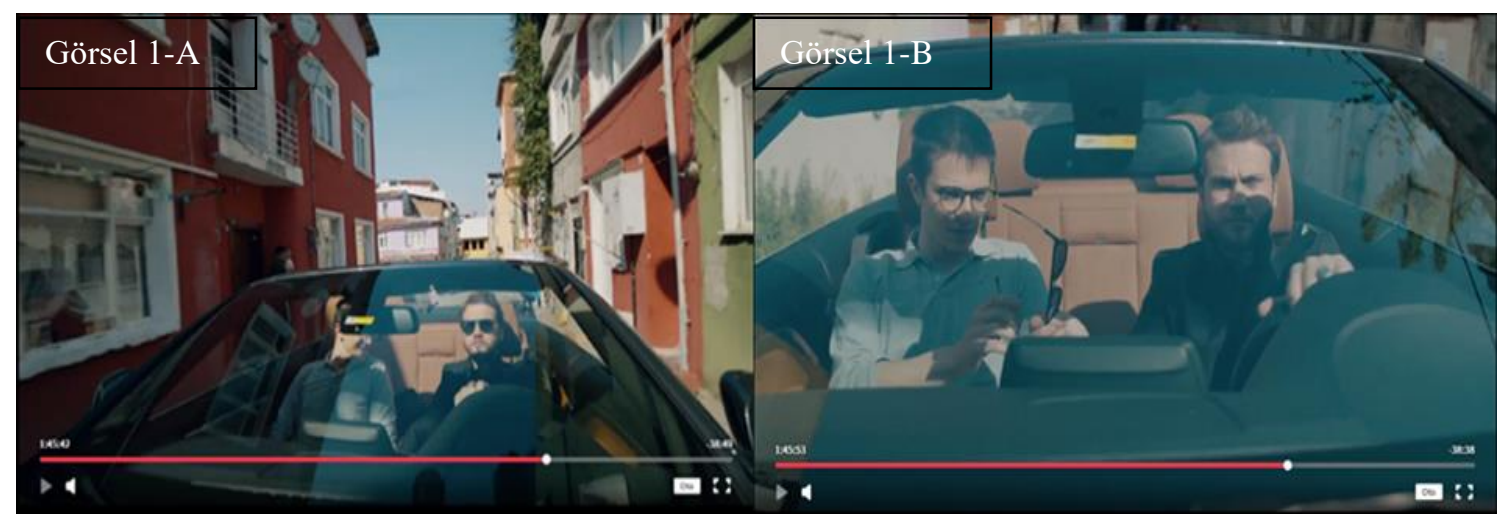

Görsel 1: Fantezi sahnesinin başlangıcı

Dizinin söylemsel içeriği ve karakter diyaloglarına bağlı olarak 2. bölümden itibaren bir şekilde izleyicinin zihninde tutulmaya çalışılan bu sahne, 27. bölüm 1:45:40' da başlar. Sahnenin başlangıcında Yamaç gözlüğünü Efe'ye verir. Bu sahne bakış’ın “object petit a” biçiminde kurulması girişimi olarak okunabilir. Çünkü Efe karakteri üzerinden (özdeşleşme) gözlüğü takan izleyicidir.

\footnotetext{
${ }^{15}$ Her ne kadar sahnelerde BMW marka sembolü gizlenmiş şekilde gösteriliyor olsa da arabanın, tasarım ve biçimi, o arabanın BMW olduğunu kanıtlar niteliktedir. Zira Linstrom'a göre (2012) güçlü marka olmanın temeli burada aranmalıdır.
} 


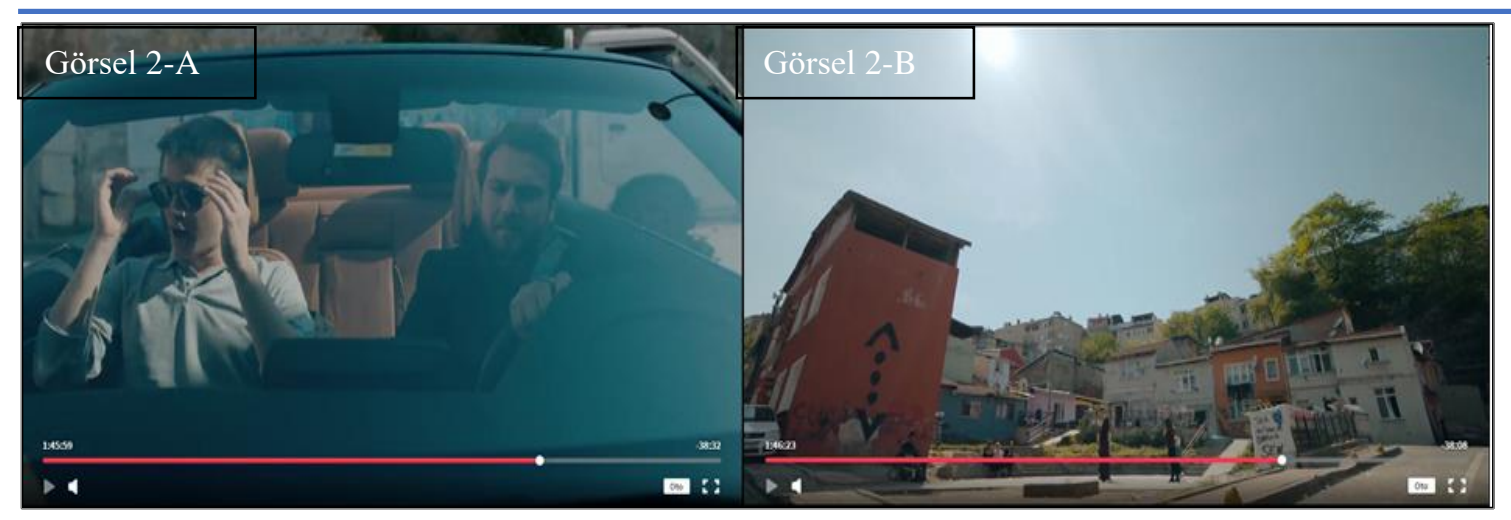

Görsel 2: Fantezi sahnesinin kurgusal gerçekliği

Efe gözlüğ̈̈ taktığı anda, Yamaç araba teybinin sesini son ses açar ve arkadan şu şarkı sözleri (ses) duyulur. "Montumun cebinde yok kuruş, zipliyor herkes kanguru sanki, bi de tepemize bas vurur, bu hayatın heyecanı meyecanı yok” (Gazapizm, 2021). Bu müzik sesi, arzu grafiğinin ikincisinde Zizek'in bahsetmiş olduğu hipnotik sese çok benzerdir. Zizek'e göre bu ses "gösterenden, anlam üreten geri dönüşlü dikme işlemini çıkardığımızda kalan şeydir” (Zizek, 2008a: 120). Sahnede ses olarak Efe'nin/izleyicinin kulağına hitap eden bu sözler çözümlendiğinde, BMW göstereninin Efe'yi/izleyiciyi nasıl bir fantezi içine soktuğu anlaş1ır. Çünkü ses, Efe'nin aslında fakir bir genç olduğunu, gündelik hayatının heyecandan yoksun olduğu (bas vurarak) kulaklarında zonklatmasına rağmen Efe, BMW göstereninin etkisinde fantezisini kat etmeye koyulur.

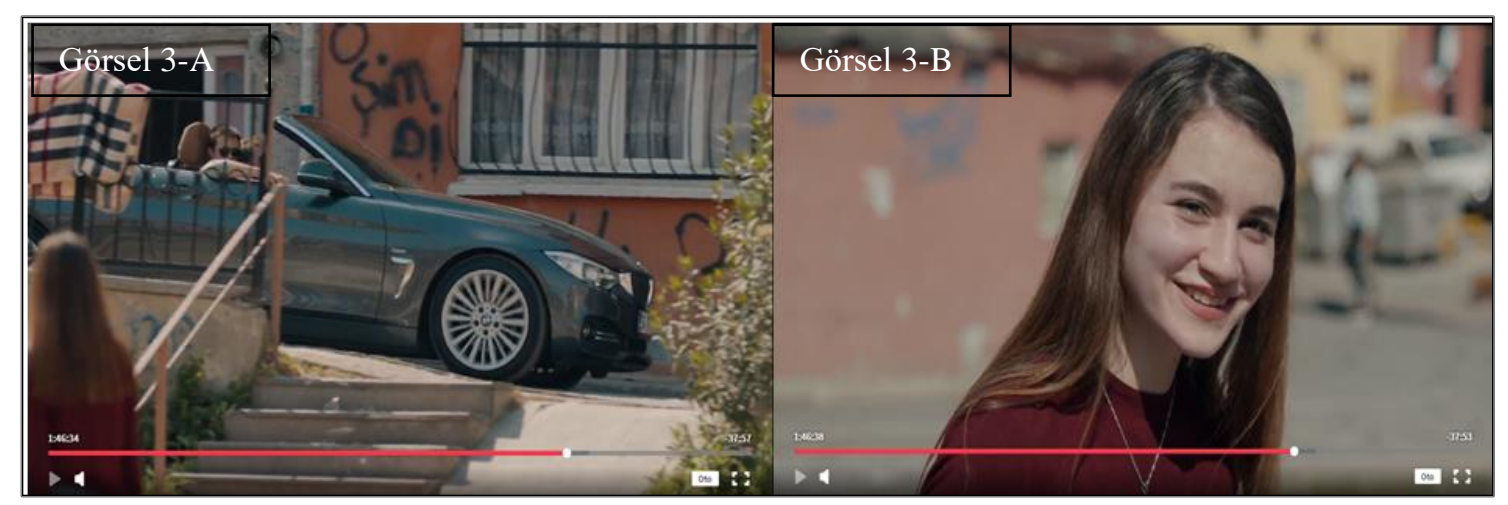

Görsel 3: Fantezinin sahnelenişi

Sahne ilerledikçe, Efe'nin sevdiği genç kadının bakışları, arabayla bütünleşmiş konumdaki Efe'ye hayranlıkla bakar şekilde gösterilir. Bu sahneleme biçimi, BMW arabasının bir "fallus gösteren” olarak Efe'nin daha önce hiç konuşamadığı genç kadının hayran bakışlarını ${ }^{16}$ kazanmasını sağlar. Bu hayran bakışın Efe'ye mi yoksa Efe'nin içinde bulunduğu BMW'ye mi yönelik olduğu bir sonraki sahnede netleşir.

\footnotetext{
${ }^{16} \mathrm{Krş.} \mathrm{öznenin,} \mathrm{anne} \mathrm{bakışı} \mathrm{(sevgisi)} \mathrm{üzerinden} \mathrm{yaşadığı} \mathrm{doyuma} \mathrm{ulaşma} \mathrm{çabası} \mathrm{olarak} \mathrm{arzu} \mathrm{(İzmir,} \mathrm{2013:} \mathrm{264-269).}$
} 


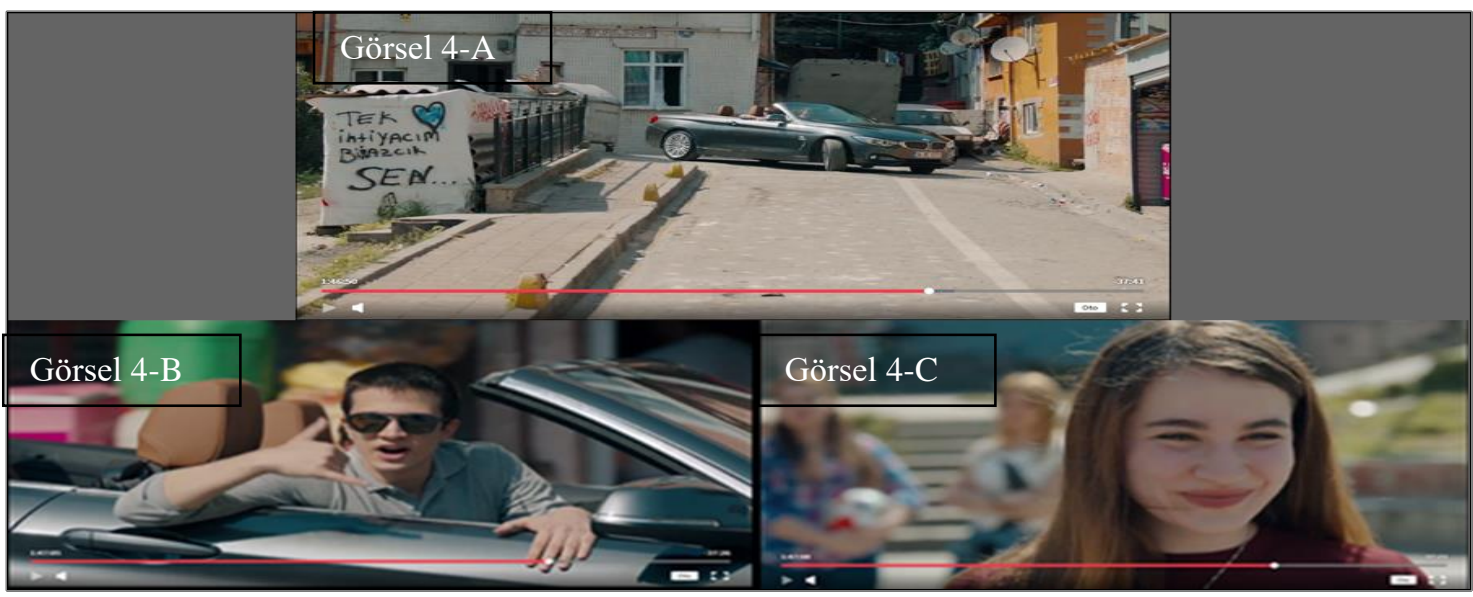

Görsel 4: Fallus gösteren olarak BMW markalı arabanın arzu nesnesi olarak konumlandırılması

Zira 4-A görselinde görüldüğü gibi BMW markalı araçla birlikte gösterilen yazıda "tek ihtiyactm birazcık sen” yazmaktadır. Fallus gösteren olarak BMW burada, “öteki’nin arzusunun arzusu” olarak konumlanmaktadır. Efe karakteri için sevdiği genç kadının arzusunun dolayımdan geçerek, arzulayacağı nesne "object petit a", BMW markalı arabadır. Çünkü bu araba içinde Efe (yani izleyici), sevdiği genç kadının dikkatini çekmiş (2-B), hayranlığını kazanmış (3-A ve 3-B) ve görüşme onayı almıştır (4-B ve 4-C).

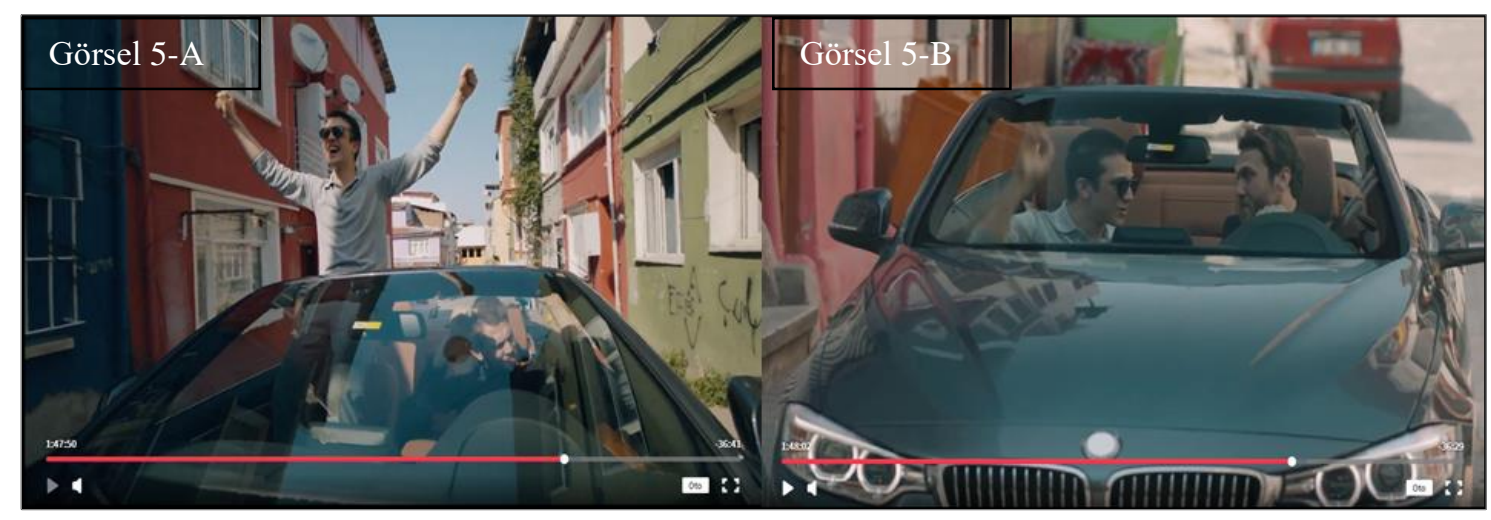

Görsel 5: Zevk'in (joussiance) sahnelenişi ve "fanteziyi kat etme”

Görsel 5-A'da Efe, yüksek bir zevk (joussiance) yaşar konumda sahnelenir. Çünkü Efe kendini, uzun zamandır (yaklaşık 25 hafta) tek bir laf edemediği (açılamadığı) sevdiği genç kadının, hayranlığını kazanmış konumda hissetmektedir. Fakat görsel 5-A ile görsel 1-A karşılaştırıldığında, Efe ve Yamaç'ın aynı yere geri dönmüş olduklarını görürüz. Bu da fantezinin aslında bir yanılsama olduğunu ve arzunun geri dönüşlü şekilde kendini yeniden kurmaya devam edeceğini hatırlatır (Zizek, 2008b: 21). Çünkü fantezi sahnesinde arzu duyulur şekilde konumlandırılan genç kadın, merkezdedir (Görsel 2-B) ve Efe sadece onun çevresinde bir tur atmış ve başladığ yere geri dönmüştür. Görsel 5-B'deki diyalogda Efe, "abi bi de ben kullansam var ya, basmıştık nişanı" derken hala fantezinin etkisindedir ve çekim açısına bakıldığında BMW, ana rolü üstlenmiş gibidir. Fakat Yamaç "ee yuh... oraya ne ara geldik" cevabıyla Efe'nin kastre oluşunu ve bu arzusuna (ve arzu nesnesine) hiçbir zaman ulaşamayacağını vurgular 


\section{Mehmet Ali GENIȘ}

\section{Arzu Pazarlaması: BMW Markasının Çukur Dizisindeki Fantezi Sahnelerine Yönelik Bir} Lacan Okumasi

gibidir. Çünkü Zizek'in fanteziyi kat etme olarak açıkladığı bu süreç, aslında arzunun tatmin edilmesi süreci değildir. Efe'nin dizi gerçekliğinde hiçbir zaman sevdiği kıza (BMW'ye) kavuşamaması da bunu destekler.

Efe karakteri, bu sahneden sonra karşımıza, 35. bölümde bulaşık yıkayıcısı olarak çıkar. Bu çıkış sahnesinde Yamaç, Çukur'lu gençler ve Efe'nin abisi tarafindan kovalanmaktadır. Efe, 35. bölümün 2:20:20'saniyesinde, Yamaç'a söylediği gibi (2. bölüm ilk diyalog) Yamaç ölmesin diye, kendi abisinin kurşununa göğüs gererek ölür. ${ }^{17} \mathrm{Bu}$ son, Zizek'in belirttiği “fanteziyi kat ettiğimizde ölüm dürtüsüne ulaşıllı" açıklamasını kanıtlar gibidir (Zizek, 2008a: 141). Hatta dizinin son bölümünde de benzer bir durum sahnelenir. Yamaç, Çukur'u sonunda kurtarır ve kalan kardeşleriyle Çukur kahvesinin önünde kendinden geçer konumda (arzu nesnesini yani "Çukur'u” elde etmiş fantezisi üzerinden) sahnelenir. Bu sahneden sonra da Yamaç'1, Baba'sının yatağında ölür şekilde izleriz.

\section{Sonuç}

Reklam söyleminde, marka konumlandırma ve cinsiyet göstergebilimi üzerinden tüketici arzusunun nasıl oluşturduğunu psikanalitik yaklaşımlar çerçevesinde çözümleyen Oswald (2010: 114), "imgesel gösteren (imaginary signifier) olarak sinemanın, görsel imajı, tüketici arzusunu ve eğlence endüstrisindeki sermaye dolaşımını birbirine bağlayan sembolik, teknolojik ve ticari bir aygıt olduğunu" savunur. Oswald, bu savunmanın gerekçesini, Metz'in (1982) sinemayı, Lacan'dan yola çıkarak “imgesel-sembolik-gerçek”i içeren çok boyutlu bir şema perspektifinden çözümlemesine bağlar. Zira Oswald'ın da belirttiği şekliyle Metz'in sinema çözümlemesi, Lacan'ın belirtmiş olduğu üç alanın diyalektiğini içinde barındırır. Bunlar; (1) Sembolik alan, bir gösteren veya temsil olarak görüntünün maddi, anlaşılır boyutunu, toplumsal olarak belirlenmiş bir semiyotik kodlar sistemini içerir. Özne, gösterenden soyut anlamlar türettiğinde, simgesel olan imgesel olana diyalektik olarak bağlanır. (2) Imgesel alan, sinema temsili düzeyinde yokluğun bir göstergesi (fiziksel gerçekliğin bir izi) olarak, bir rüya makinesidir; izleyiciyi (tüketiciyi) sahne içindeki dünyayla özdeşleşmeye davet eder. (3) Gerçek alan, sinema endüstrisinde marka imajlarının oluşturulduğu, reklamcılık, para ve pazarlamanın yakınlaşmasıyla yaratılan maddi üretimleri açıklar (Oswald, 2010: 114-115). Bu diyalektik çerçevede Metz'in ve Oswald'tın belirttiği gibi, izleyicinin temel bakış açısı sembolik ve imgesel alanda sabitlenerek, sermayenin ve pazarlama stratejilerinin alanı olarak "gerçek" alan, izleyicinin bakışından kaçırılmaya çalışılır. Çünkü medyanın gücü, üretimin teknik ya da ticari süreçlerinin maskelenmesinden ya da inkâr edilmesinden kaynaklanır. Fakat Çukur dizisinin bölüm sonlarında yer alan ve sponsor görsellerinin sahnelendiği kısımda, şu görseli izleriz.

\footnotetext{
${ }^{17}$ Dizi sahneleri içinde Efe'nin gömülme sahnesi yoktur. Sadece 37. bölüm 0:49:10. saniyede abisinin elleriyle toprağa verdiği söylenir. Bu tercih Efe'nin arzusunun yok olmadığı, serbest kaldığı ve imgelemimizde dolaşmaya devam ettiği hissini uyandırma amacı taşıyor olabilir.
} 


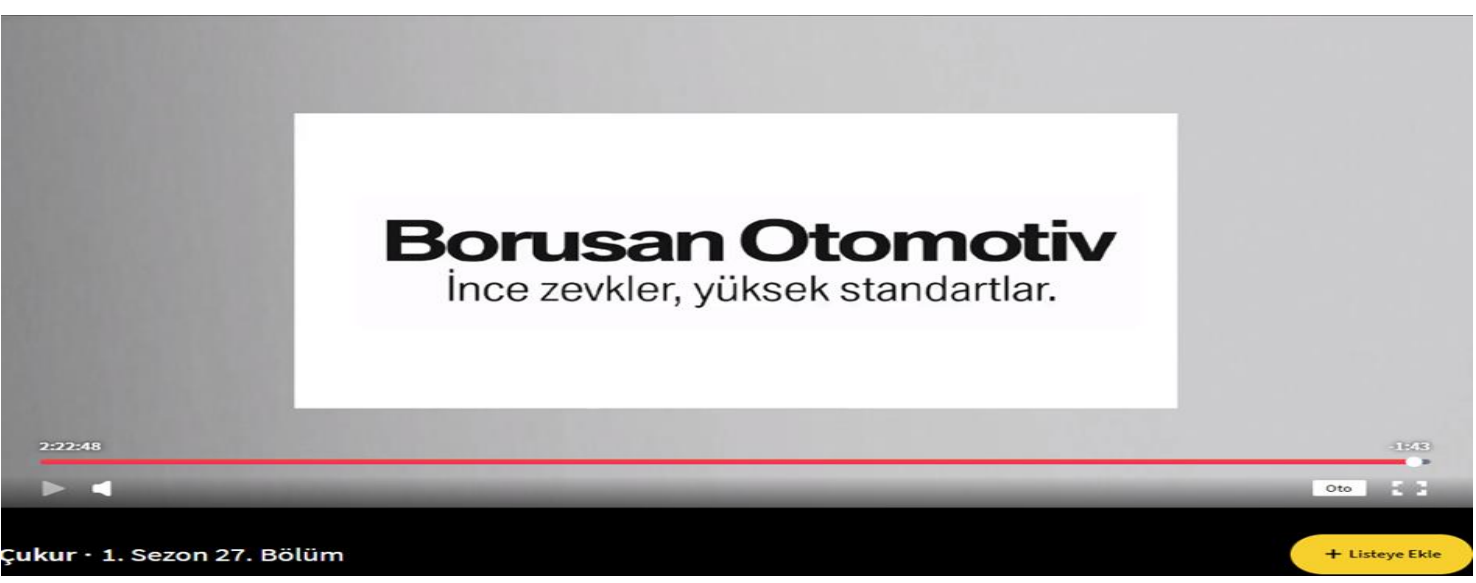

Görsel 6: Çukur dizisinin "gerçek"i borusan otomotiv

Görsel 6, Çukur dizisinin simgesel-imgesel gerçekliğine gizlenen "gerçek"in aslında ne olabileceği hakkında bizlere fikir verir. Zira Gökhan Horzum ve Ercan Kesal'ın katıldığı Marka Konferansı'nda (2018) Kesal'ın ağzından şu sözler dökülür. 'Sadece oyunculuk bazında değil ilişkiler anlamında da senaristimizle, yapımcımızla ve sektörün diğer aktörleriyle de gerçekten ilişkiyi pozitif düzeyde sürdürdügümüz bir dizi oldu Çukur." Sektörün diğer aktörlerinin içinde, dizi/sinema sektörünü özellikle maddi anlamda destekleyen markaların yer aldığı söylenebilir (Çetindağ, 2018). Çünkü küresel bir marka olarak BMW, dizi gerçekliğinde gizlenen fakat aynı zamanda kapitalist arzu ekonomisinin sürdürülebilir "gerçek”inde yer alıp, izleyicinin bilinçdışına seslenen bir gösterendir ve bu gösterenin Türkiye Temsilcisi Borusan Otomotiv'dir. Bu çerçevede Çukur dizisinde yer alan BMW fantezi sahnelerinin, belli bir sponsorluk ya da reklam geliri üzerinden sahneye konmuş olduğu savunulabilir. Yani küresel bir marka olarak BMW, Türkiye yerelinde, yerel ülkenin kültürüne uyumlu bir dizi gerçekliği (fantezisi) üzerinden, marka gösteren değerini artırmayı amaçlamaktadır. BMW marka uzmanlarının (ya da anlaştıkları reklam ajansının) bu amaca ulaşabilmeleri ancak, Efe ve diğer dizi karakterleriyle özdeşleşecek izleyicilerin arzularını/arzu nesnelerini sahnelenen bu fantezinin içinde kurmalarına bağlıdır. Zira yine Marka Konferansı'nda (2018) Kesal'ın değindiği gibi “ínsanlar içinde olmak istedikleri dünyayı sever ve takip ederler. Arzuladıkları, bir katarsis yaşadıkları dünyayı isterler. Çukur onlara, bunları sundu... Seyirci arzuladı̆̆ dünyayı Çukur'da gördü." Arzulanacak olan dünyanın Çukur'da sahnelenmiş olması, arzu nesnesinin de Çukur'un kendinde ya da Çukur dizisinin imgesel-simgesel gerçekliğine gizlenen gösterenlerde temsil edilmiş olduğunu açıklar. Bu açıdan BMW fantezisinin Çukur dizisindeki sahnelenme biçimi, kapitalist arzu ekonomisinin/pazarlamasının ideolojik politikasına oldukça uyumlu görünür.

\section{Kaynakça}

Aaker, D. A. (2009). Managing brand equity: Capitalizing on the value of a brand name. Newyork: Free Press.

Aaker, J. L. (1997). Dimensions of brand personality. Journal of Marketing Research, 34(3), 347-356. 
Alderson, W. (1952). Psychology for marketing and economics. Journal of Marketing 17(2), 119-135.

Anderson, P. F. (1983). Marketing, scientific progress, and scientific method. Journal of Marketing, 47(4), 18-31.

Arvidsson, A. (2005). Brands: A critical perspective. Journal of Consumer Culture, 5(2), 235-258.

Bagozzi, R. P. (1995). Reflections on relationship marketing in consumer markets. Journal of the Academy of Marketing Science, 23(4), 272-277.

Bakır, B. (2008). Sinema ve psikanaliz, Hayalet Kitap.

Bargh, J. A. (2002). Losing consciousness: Automatic influences on consumer judgment, behavior, and motivation. Journal of Consumer Research, 29(2), 280-285.

Belk, R. W., Ger, G., \& Askegaard, S. (2003). The Fire of Desire: A multisited inquiry into consumer passion. Journal of consumer research, 30(3), 326-351.

Bernays, E. (1923). Crystallizing public opinion, Boni \& Liveright, Inc.

Bernays, E. (1928). Propaganda, Ig publishing.

Boyd III, H. C. ve Helms, J. E. (2005). Consumer entitlement theory and measurement. Psychology \& Marketing, 22(3), 271-286.

Buttle, F. (1989). The social construction of needs. Psychology \& Marketing, 6(3), 197-210.

Calder, B. J. ve Tybout, A. M. (1987). What consumer research is... Journal of Consumer Research, 14(1), 136-140.

Cluley, R. ve Desmond, J. (2015). Why psychoanalysis now?. Marketing Theory, 15 (1), 3-8.

Cochoy, F. (1998). Another discipline for the market economy: Marketing as a performative knowledge and know-how for capitalism. The Sociological Review, 46(1), 194-221.

Çetindağ, S. (2018). Türkiye'de televizyon yayıncılığının yeni medya ortamlarıyla dönüşüm süreci: içerde ve çukur dizisi örneğinde yeni yayıncılık ekosisteminin incelenmesi. Hacettepe Üniversitesi Sosyal Bilimler Enstitüsü Yüksek Lisans tezi.

De Ruyter, K. ve Scholl, N. (1998). Positioning qualitative market research: Reflections from theory and practice. Qualitative market research: An International Journal, 7-17.

Desmond, J. (2012). Psychoanalytic accounts of consuming desire: Hearts of darkness, Springer.

Dichter, E. (1947). Psychology in market research. Harvard business review, 25(4), 432-443.

Dichter, E. (1949). A psychological view of advertising effectiveness. Journal of Marketing, 14(1), 6166.

Dichter, E. (1960). The strategy of desire. Transaction Publishers.

Dichter, E. (1986). Ernest dichter: Motive interpreter. Journal Of Advertising Research 26(1), 15-20.

Dominici, G., Tullio, V., Siino, G. ve Tani, M. (2016). Marketing archetypes: Applying jungian psychology to marketing research. Journal of Organisational Transformation \& Social Change, 13(2), 109-122.

Elliott, R. (1997). Existential consumption and urrational desire. European Journal of Marketing. 31(3/4). 285-296.

Erkılıç, H. (2015). Sinema politikaları: Söylem, psikanaliz, ideoloji. Sinecine: Sinema Araştırmaları Dergisi, 6(2), 77-90.

Fantezi Sahnesi (2021). Erişim Adresi: https://www.youtube.com/watch?v=Ye2enrj4rw8 (08.07.2021)

Foucault, M. (1991). Governmentality. Burchell G, Gordon C and Miller P (Ed.) The Foucault Effect. Chicago, IL: University of Chicago Press, pp. 87-104. 
Freud, S. (2012). The basic writings of Sigmund Freud. Modern Library.

Fullerton, R. A. (1988). How modern is modern marketing? Marketing's evolution and the myth of the "Production Era". Journal of Marketing, 52(1), 108-125.

Fullerton, R. A. (2007). Mr. Mass Motivations Himself': Explaining Dr. Ernest Dichter. Journal of Consumer Behaviour: An International Research Review, 6(6), 369-382.

Forest, F. (2016). Psychoanalysis of advertising. International Journal of Applied Psychoanalytic Studies, 13(4), 338-350.

Gabbard, G. O. and Gabbard, K. (1999). Psychiatry and the cinema. American Psychiatric Pub.

Gammelgaard, J. (2011). Love, Drive and desire in the works of Freud, Lacan and Proust. The International Journal of Psychoanalysis, 92(4), 963-983.

Gazapizm, Heyecanı Yok, Erişim Adresi: https://www.youtube.com/watch?v=BcjoGIoErdE (06.07.2021)

Geçtan, E.(1996). Psikanaliz ve sonrası, Ankara: Remzi Ya.

Güven, F. (2019). Medya kahramanı ile kurulan parasosyal etkileşim bağlamında kültür ve sürdürülebilirliği. Motif Akademi Halkbilimi Dergisi, 12(28), 956-969.

Gorz, A. (2011). Maddesiz: Bilgi değer ve sermaye (çev. Işık Ergüden). İstanbul: Ayrıntı Ya.

Güler, M. (2019). Yönlendirilen arzu: Tüketim kültürü, reklam, psikanaliz. Ankara: Ütopya Ya.

Harding, B. (2007). Dialectics of desire and the psychopathology of alterity: From levinas to Kierkegaard Via Lacan 1. The Heythrop Journal, 48(3), 406-422.

Holbrook, M. B. (1987). What is consumer research? Journal of Consumer Research, 14(1), 128-132.

Holt, D. B. (2006). Toward a sociology of branding. Journal of Consumer Culture, 6 (3), 299-302.

Horzum, G. (2019). Çukur: Yamaç'ın dönüşü. İstanbul: Doğan Kitap.

İpek, İ .(2020). Kurtlar vadisi ve çukur dizisinin şiddet ve suç eylemleri üzerindeki etkisi. Maltepe Üniversitesi İletişim Fakültesi Dergisi, 7(1), 122-137.

İzmir, M. (2013). Öznenin diyalektiği: Hegel, Sartre ve Lacan. Ankara: İmge Ya.

Keskin, Y. (2008). içine ulaşılan, ötede bırakılan şato: tanıma arzusu bağlamında Hegel ve Lacan. MonoKL Uluslararası Hegel Özel Sayısı, 340-355.

Kotler, P. (1965). Behavioral models for analyzing buyers. Journal of Marketing, 29(4), 37-45.

Krishnan, H. S. ve Trappey, C. V. (1999). Nonconscious memory processes in marketing: A historical perspective and future directions. Psychology \& Marketing, 16(6), 451-457.

Kurultay, A. B. (2017). Arketipler: Markaların yeni anlam yaratıc1ları. Global Media Journal TR Edition, 7(14), 352-370.

Lacan, J. (2006). The Subversion of the subject and the dialectic of desire. Écrits. (çev. Bruce Fink) New York and London: Norton

Lacan, J. (2015). Dinin zaferi (çev. Çetin Kurt). İstanbul: 6:45 Ya.

Lacan, J. (2013), Fallus'un anlamı. (çev. Saffet Murat Tuna), İstanbul: 6:45 Ya.

Lacan, J. (2017). Psikanalizin dört temel kavramı: Seminer 11. Kitap (çev. Nilüfer Erdem). İstanbul Metis Ya.

Lämmlein, B. (2014). Archetypes and mythical narratives in car advertising. Romanian Journal of Journalism \& Communication/Revista Romana de Jurnalism si Comunicare-RRJC, 9(3).

Lazarsfeld, P. F. (1934). The psychological aspect of market research. Harvard Business Review, 13(1), 54-71. 
Lesourd, S. (2018). Özne nasıl susturulur: Söylemlerden liberal laf ebeliklerine (çev. Özge Soysal). Ankara: Doğu Batı Ya.

Levy S., J. (1959). Symbols for sale. Harvard Business Review, 37(4), 117-124.

Lindstrom, M. (2012). Buyology: How everything we believe about why we buy is wrong. Random House.

Marka Konferansı (2018) Erişim Adresi: https://www.haberturk.com/video/tv/izle/marka-2018decukur-firtinasi/575533

Mascelli, J. V. (1965). The Five C'S Of Cinematography. Grafic Publications.

McGowan, T. (2012). Gerçek bakış: Lacan sonrası sinema kuramı (çev. Zynep özen Barkot). İstanbul: Say Ya.

McGowan, T. (2018). Sahip olmadığımız şeyin keyfini sürmek: psikanalizin politik projesi (çev. Kemal Güleç). Ankara: İmge Ya.

McGowan, T. (2020). Lacan and contemporary film. Other Press, LLC.

Metz, C. (1982). The Imaginary signifier: Psychoanalysis and the cinema. Indiana University Press.

Metz, C. (2012). Sinemada anlam üstüne denemeler (çev. Oğuz Adanır). İstanbul: Hayalperest.

Negri, A. ve Hardt, M. (2000). Empire. Cambridge, MA: Harvard University Press.

Nelson, M. R. (2008). The hidden persuaders: Then and Now. Journal of Advertising, 37(1), 113-126.

Ormanlı, o. (2011). Başlangıç filminde psikanalitik öğeler ve rüya olgusu. Yedi, (6), 55-62.

O'Shaughnessy, J. (1987). Why people buy. Oxford University Press on Demand.

O'Shaughnessy, J. (2015). Note on the marginalizing of psychoanalysis in marketing. Marketing Theory, 15(1), 17-19.

Oswald, L. R. (2010). Marketing hedonics: Toward a psychoanalysis of advertising response. Journal of Marketing Communications, 16(3), 107-131.

Packard, V. (1957). The hidden persuaders. New York: David McKay; Pocket Books, Cardinal edition.

Papatya, N. ve Özdemir, Ş. (2015). Kültürel anlam üretiminde çokuluslu şirketlerin ideolojik marka iletişim aracı olarak Hollywood sineması: "forrest gump" filminin sinematografik imaj analizi. Süleyman Demirel Üniversitesi İktisadi ve İdari Bilimler Fakültesi Dergisi, 20(2), 128.

Papatya, N. ve Geniş, M. A. (2018). Reklamlarda ideolojik dil ve söylem: Norman Fairclough ekseninde eleştirel bir değerlendirme. Mehmet Akif Ersoy Üniversitesi İktisadi ve İdari Bilimler Fakültesi Dergisi, 5(3), 954-976.

Papatya, N. ve Geniş, M. A (2019). Hegemonik güç olarak pazarlama ideolojisi nasıl "yanlış bilinç" üretebilir? kültürel okumalar üzerinden eleştirel duruş ve çözümleme. Süleyman Demirel Üniversitesi İktisadi ve İdari Bilimler Fakültesi Dergisi, 24(4), 1031-1043. 1039.

Parsons E., Maclaran P. ve Chatzidakis A. (2017). Psychoanalysis in marketing theory and practice. Parsons, E., Maclaran, P., \& Chatzidakis, A. (Edt.). Contemporary issues in Marketing And Consumer Behaviour. Routledge.

Pratkanis, A. R., \& Greenwald, A. G. (1988). Recent perspectives on unconscious processing: Still no marketing applications. Psychology \& Marketing, 5(4), 337-353.

Reichert, T. ve Lambiase, J. (2013). Peddling desire: Sex and the marketing of media and consumer goods. (Edt.) In Sex in Consumer Culture. Routledge.

Ries, A. ve Trout, J. (2001). Positioning: The battle for your mind. McGraw Hill. 
Sarı, E. ve Nezir, M. C. (2020). Popüler bir suç dramasında adalet: Çukur dizisi izleyicilerinin adalet anlayışları üzerine nicel bir araştırma. Electronic Turkish Studies, 15(5). 2589-2624.

Schwartzkopf, S. ve Gries, R. (2010). Ernest Dichter and motivation research: New perspectives on the making making of post-war consumer culture. London: Palgrave MacMillan.

Schwarzkopf, S. (2015). Mobilizing the depths of the market: Motivation research and the making of the disembedded consumer. Marketing Theory, 15(1), 39-57.

Skålén, P., Fellesson, M., ve Fougère, M. (2006). The Governmentality of marketing discourse. Scandinavian Journal of Management, 22(4), 275-291.

Stavrakakis, Y. (2006). Objects of consumption, causes of desire: Consumerism and advertising in societies of commanded enjoyment. Gramma: Journal of Theory and Criticism, 14, 83-105.

Stern, B. B. (1990). Literary criticism and the history of marketing thought: A new perspective on "reading" marketing theory. Journal of the Academy of Marketing Science, 18(4), 329-336.

Tadajewski, M. (2006a). The ordering of marketing theory: The influence of mccarthyism and the cold war. Marketing Theory, 6(2), 163-199.

Tadajewski, M. (2006b). Remembering motivation research: Toward an alternative genealogy of interpretive consumer research. Marketing Theory, 6(4), 429-466.

Tadajewski, M. (2013). Promoting the consumer society: Ernest Dichter, the Cold War and FBI. Journal of Historical Research in Marketing.

Tomsiç, S. (2017). Kapitalist bilinçdışı (çev. Barış Engin Aksoy). İstanbul: Metis Ya.

Turan, M. (2013). Kuyu filmindeki arzu kavramının lacancı psikanalitik yaklaşım çerçevesinde çözümlenmesi. Selçuk İletişim, 7(4), 169-185.

Üstündağ, A. (2019). Gençlerin model aldıkları televizyon karakterleri. Akademik Incelemeler Dergisi, 14(1), 27-50.

Van Leeuwen, A. (2017). Simone de beauvoir and the dialectic of desire in l'invitée. A Companion to Simone de Beauvoir, 356-366.

Williamson, J. (1978). Decoding advertisements: Ideology and meaning in advertising. Marion Boyers.

Žižek, S. (2006). The Matrix, or the two sides of perversion. (Edt.) The International Handbook of Virtual Learning Environments (pp. 1549-1569). Springer, Dordrecht.

Žižek, S. (2008a). İdeolojinin yüce nesnesi, (çev.Birkan, T.) İstanbul: Metis Ya.

Žižek S. (2008b). Yamuk bakmak: Popüler kültürden Jacques Lacan'a giriş. (çev. Tuncay Birkan) İstanbul: Metis Ya.

Žižek, S. (2008c). Enjoy your symptom!: Jacques Lacan in Hollywood and out. Taylor \& Francis.

Žižek, S. (2014). Ahir zamanlarda yaşarken (çev. Erkal Ünal), İstanbul: Metis Ya.

Žižek, S. (2016). Can one exit from the capitalist discourse without becoming a saint. Crisis and Critique, 3(3), 481-499.

Zupančič, A. (2008). Why psychoanalysis? Three interventions. Copenhagen and Helsinfors: Nordic Summer University Press.

Zwick, D.ve Bradshaw, A. (2016). Biopolitical marketing and social media brand communities. Theory, Culture \& Society, 33(5), 91-115. 